\title{
A Systematic Literature Review of Bio, Green and Circular Economy Trends in Publications in the Field of Economics and Business Management
}

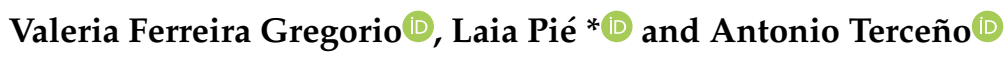 \\ Markets and Financial Analysis Research Group, Department of Business Management, \\ Faculty of Business and Economics, Universitat Rovira i Virgili, 43205 Reus, Spain; \\ valeria.ferreira@urv.cat (V.F.G.); antonio.terceno@urv.cat (A.T.) \\ * Correspondence: laia.pie@urv.cat; Tel.: +34-977-759-818
}

Received: 27 September 2018; Accepted: 13 November 2018; Published: 16 November 2018

check for updates

\begin{abstract}
The concepts of bioeconomy, green economy and circular economy share the common objective of developing a sustainable economy, and they attract enormous political, academic, social and business interest. However, an analysis of these concepts in the fields of economics and business management is lacking. The objective of this article is to classify the publications on these topics by subject of study, to analyse trends in publications and to guide researchers interested in selecting articles. The review was performed using Scopus for the period 1960 to 2017. Four hundred and forty-nine publications were obtained and classified into 17 categories. The results show that the existing literature is rich in analysing implemented policies and issues related to the strategies and organizational models of companies looking for a more sustainable path, and research in China and the European Union is highlighted. However, there is still a long way to go in researching implemented case studies and evaluating the economic impact of these concepts. For this to happen, the need to promote, encourage and support companies to implement cleaner production and approach a more sustainable path must be prioritised. Possible gaps in current research that allow future lines of work are also identified.
\end{abstract}

Keywords: systematic literature review; bioeconomy; green economy; circular economy; bibliometric analysis; sustainability management

\section{Introduction}

To ensure a sustainable growth model we have to use our resources more efficiently [1], which, in turn, requires focusing on sustainable development, as defined by the United Nations in its 1987 "Report of the World Commission on Environment and Development".

Taking as a starting point the key concept of natural capital as the world's stock of natural assets—such as air, water, soil, geology and all living organisms, whether renewable or not [2] — then it is essential to consider the conservation of this natural capital to ensure the future of humanity. If we continue to reduce reserves of natural resources without replenishment, we run the risk of ecological collapse. Badly managed natural capital becomes a social and economic responsibility and sustainability depends on its maintenance [3]. Consequently, our economy cannot be based on a "take, make, consume and dispose" model, and consumers, governments and businesses must be aware of this reality.

The importance of this issue has led to its inclusion in worldwide agendas, for example, "The 2030 Agenda for Sustainable Development" [4], which seeks to promote countries' commitment to a better future. The United Nations has established seventeen goals for sustainable development, which 
should be addressed by all member countries. The three concepts analysed in this article have a direct impact mainly on these goals, which promote sustainable industries focusing on responsible production and consumption through the efficient use of resources and energy and reduction of waste. This situation impacts the creation of new products, increasing competitiveness in new markets, and promoting sustainable economic growth with quality employment without harming the environment. For example, the bioeconomy will contribute to promoting sustainable agriculture (which, in turn, provides food security), accessing energy through the use of clean energies, and guaranteeing the conservation of biodiversity and the sustainable use of ecosystems. Moreover, these new forms of production and consumption will help combat climate change. However, it must be pointed out that these concepts will also have an indirect impact on other established goals, such as clean water and sanitation (6) and life below water (14).

The OECD and the European Union are addressing this subject with the aim of creating international co-operation and promoting its implementation in as many countries as possible. The European Commission's "Europe 2020" strategy considers that developing a smarter and greener Europe is essential [5]. To this effect, various strategies and policies have been published in recent years: in 2008 "Europe's climate change opportunity"; in 2010 "A strategy for smart, sustainable and inclusive growth"; and, in 2011 "A resource-efficient Europe-Flagship initiative under the Europe 2020 Strategy" [6]. The latter declares the need for more efficient use of resources, minimising waste generation and optimising production processes both for the sake of the environment and to be more cost-effective and competitive. The policy document sets out measures and actions to be implemented in the next 10 years with the aim of promoting smart, inclusive, sustainable growth [7]. Each country, region or city must identify its own priorities, needs and goals to be able to promote policies tailored to its particular situation while contributing to global goals. Examples include: OECD (2009), “The Bioeconomy to 2030. Designing a policy agenda"; EU (2012), "Innovating for Sustainable Growth: A Bioeconomy for Europe"; USA (2012), “National Bioeconomy Blueprint”; Germany (2014), "National Policy Strategy on Bioeconomy"; Finland (2014), "Finnish Bioeconomy Strategy"; Spain (2016), "Spanish Bioeconomy strategy-2030 Horizon"; EU (2015), "Closing the Loop-An Action Plan for the Circular Economy EU 2015"; China (2009), "Circular Economy Promotion Law”; Spain (2018), "Circular Spain 2030—Spanish Circular Economy Strategy"; Catalonia (2015), "Andalusian Strategy of Circular Bioeconomy"; Andalusia (2018), "Strategy promoting Green and Circular Economy"; and, Netherlands (2016), "A Circular Economy in the Netherlands by 2050" [8,9].

In this article we analyse the publications that have been grouped under the concepts circular economy (CE), green economy (GE) and bioeconomy (BE), all of which are linked by the common objective of promoting sustainable development [10].

The concept of the GE was first introduced by Pearce et al. (1989) [10,11], who established that the economy and the environment are not separated, but are interdependent concepts. The United Nations Environment Program [12] defines the GE as one that "improves human well-being and social equity, while significantly reducing environmental risks and ecological scarcities". It seeks to implement economic models able to generate profit while avoiding damage to the environment, considering eco-innovation, improved resource and waste management, the reuse of raw materials and the transition towards sustainable consumption and production.

Several articles agree that Pearce and Turner introduced the concept of the CE in 1990 [13-15], originating from the desire to substitute the prevailing traditional linear economic model with a circular one whose principal aim was to keep the value of products, materials and resources in the economy for as long as possible. This model minimizes waste and the consumption of resources and foresees that goods generate value through their use at the end of their useful life [13]. It is based on four principles, the so-called 3Rs—reduce, reuse and recycle-and a fourth principle, sustainable design strategies to achieve greater durability in the designed products, incorporated by the Ellen MacArthur Foundation [16-18]. 
The BE is considered to have been introduced in 1971 by the economist Georgescu-Roegen, who affirmed that "the economy must be a branch of biology ( . . . ) we are one of the biological species of this planet and as such we are subject to all the laws that govern the existence of terrestrial life" $[8,10,19]$. In its strategy document, "Innovating for sustainable growth: A bioeconomy for Europe" (2012), the European Commission defines the BE as "an economy that covers the production and use of renewable biological resources (land and sea) and the conversion of these resources and waste into value-added products, such as food, feed, biological products and bioenergy" [20,21]. According to McCormick and Kautto (2013), the BE is based on the more efficient use of resources, reduced dependence on non-renewable resources, mitigating climate change, providing food security thanks to the use of renewable resources for industrial purposes, and increasing competitiveness and employment in companies. At a global level, increased adoption of bioeconomy strategies in recent years can be observed $[6,8,22,23]$.

The current importance of the subjects BE, CE and GE is confirmed by the huge increase in scientific literature. However, just one literature review article currently exists that includes the three concepts and analyses the diversity within and between them with respect to sustainability [10]. Noteworthy is the work [24] in which a theoretical basis is developed to understand the different models applied to companies that want to make a transition towards a more sustainable economy, with a special application to the CE. There is also a systematic literature review that contributes to a fuller understanding of the academic studies but only focuses on $\mathrm{CE}$, which has been taken as a reference [25]. Within this context, we carry out a systematic literature review about the BE, the CE and the GE based on analyzing publications within the field of economics and business management, an area still not addressed.

The first objective of this article is to explore the publications within the field of economics and business management by carrying out a descriptive analysis, which identifies their origin, the most popular sources and the authors. The second aim is to analyse the current literature on the three topics and categorise it according to the subject of study, identifying trends in publications in these fields and determining the most important issues and contributions, in addition to the country and the sector. The last aim is to identify possible gaps in the literature, allowing us to advance some future lines of research. The rest of this work is organised as follows: in Section 2 the methodology applied to carry out the systematic literature review is presented, including the planning and execution stages; in Section 3, the results are analysed; in Section 4, the results are discussed; and in Section 5, the conclusions are drawn.

\section{Methodology}

With the aim of producing a set of recommendations on the steps to follow to carry out a systematic literature review (SLR) in the area of management, Tenfield et al. (2003) proposed a three-stage process: planning, execution, and reporting and dissemination. This recommended procedure is followed for this analysis [26].

\subsection{Planning the SLR}

To achieve our objectives, the terms selected were used in the following way to search the title, abstract and key words: "Circular Economy" OR "Bioeconomy" OR "Bio-economy" OR "Green Economy".

The Scopus database was chosen to ensure the quality of the review. It provides a global view of scientific contributions with access to approximately 18,000 scientific publications from more than 5000 international publishers, covering 16,500 journals in the areas of science, technology, medicine, social sciences, art and humanities. It was chosen mainly because it contains more publications and journals than the Web of Science, but also because it offers about $20 \%$ more coverage in citations and includes different tools allowing the researcher to visualise, analyse and compare the published scientific information to make a descriptive analysis. In this case, Google Scholar was discarded 
because the citations analysis it provides is not accurate and its search filters not useful for this analysis. Scopus is limited to articles published from 1966 onwards and the citation analysis is only available for articles published after 1996. These limitations, however, did not hinder our research, which is based on recent years [27].

\subsection{Executing the SLR}

The initial Scopus search based on the selected words appearing in titles, abstracts or key words between January 1970 and November 2017 identified a total of 4194 publications. The results indicated a considerable increase in publications since 2009 and particularly since 2016. By limiting the search to "articles", "articles in the press", "reviews", "books" and "book chapters", a total of 3043 publications were obtained. Considering only the publications in journals and books, there were 2594 articles in journals and 377 works in books. After selecting the languages English and Spanish, the total number of documents obtained was 2728 .

The fields mainly involved in these articles are: Environmental Science, Social Science, Energy, Engineering, Economics, Econometrics and Finance, Business, Management and Accounting. However, to achieve the aims established in this SLR, of the resulting 2728 documents only those included in the fields of economics, econometrics, finance, business, management and accounting were selected, obtaining a total of 785 publications.

Due to the significant number of articles found and considering that those of greatest interest here would be the ones that incorporated the searched words in the key words, they were included in a new filter, obtaining 410 publications.

Having concluded the selection process, the works not included in the previously selected areas were analysed. It was considered opportune to incorporate 39 of the articles published in journals not classified within the fields chosen because they contained information related to our objective of study (with content related to economic or management issues) and they were cited in previously selected articles (numbering 410) (Figure 1). The "snowball" technique, a data collection method often used when it is difficult to obtain a representative sample in official sources, was applied to include these items $[15,28,29]$. A final total of 449 publications was obtained. They are detailed in Figure 2 by year of publication, and the huge increase in the importance of these topics in recent years is evident. In fact, $87 \%$ of the publications were published since 2013 , of which $59 \%$ were published in the last two years, 2016 and 2017.

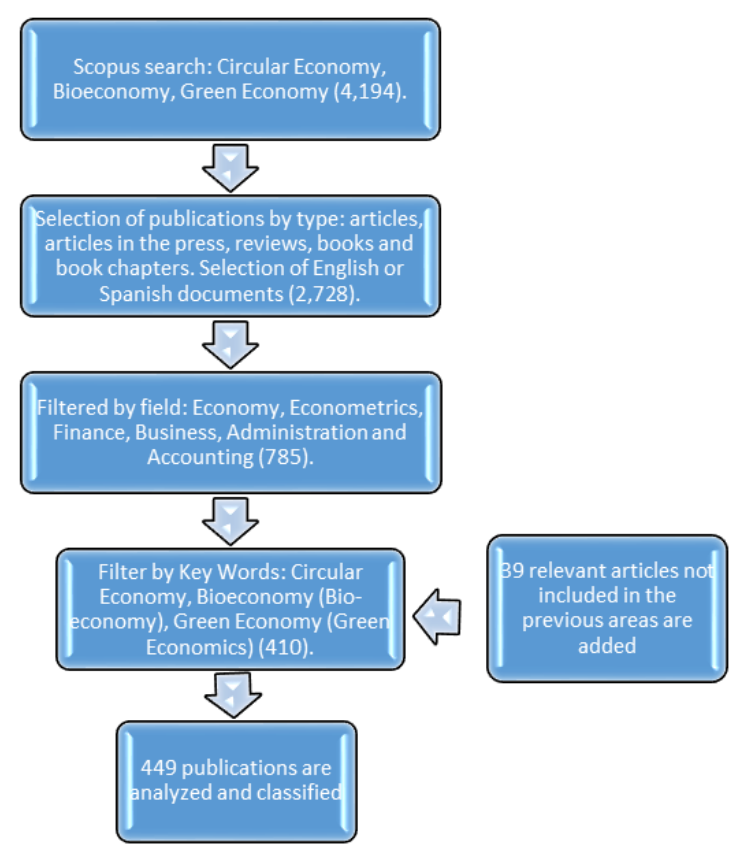

Figure 1. Systematic literature review process. 


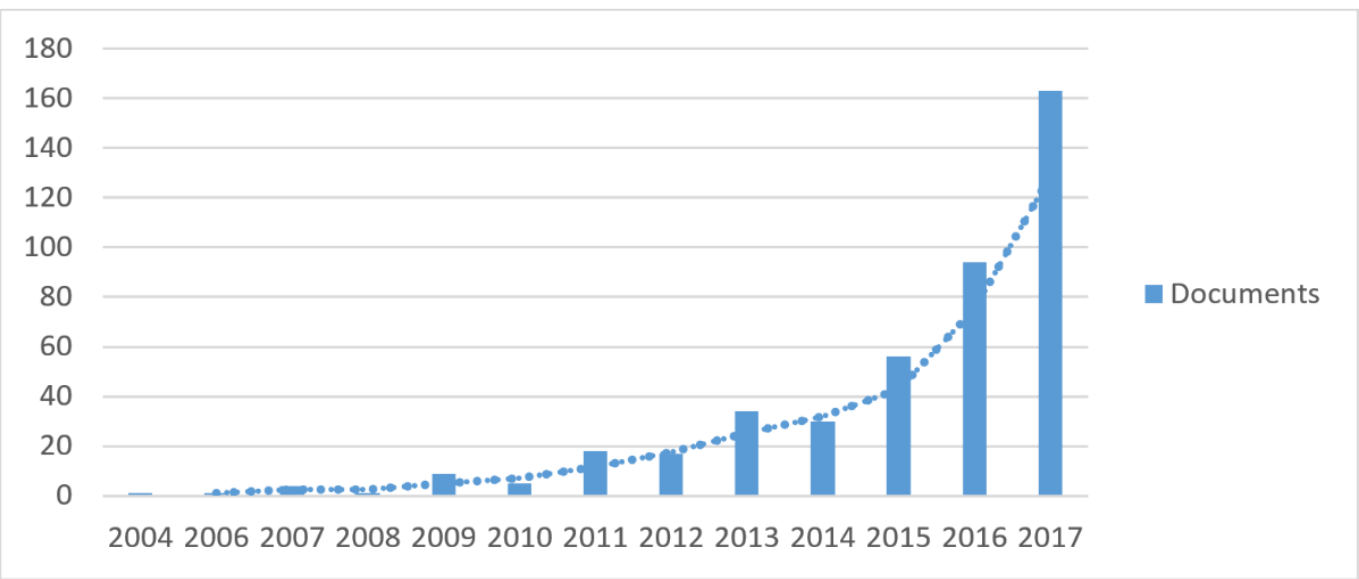

Figure 2. Search including key words.

\section{Results}

In this section, the results of the bibliography analysis are described, a content analysis to categorise the results by topic of study is made, and trends in publications and most important contributions are analysed.

\subsection{Analysis of the Evolution of the Literature}

A total of 449 publications were obtained from the execution stage of the SLR. The number of publications in 2015, 2016 and 2017 increased significantly, as did future publications for 2018. These topics were published by 135 journals, with 19 of them publishing four or more articles, representing $64 \%$ of the total. Analysing the Scopus impact evaluation of sources with the most publications, $63 \%$ were in the first quartile, $21 \%$ in the second and $16 \%$ in the third, demonstrating the high standard of the publications and the level of interest in the subject. It was also observed that $68 \%$ of the journals were indexed in the Web of Science and $47 \%$ were in quartile 1 , according to the Journal Citation Reports (Table 1).

Table 1. Journals with four or more documents published.

\begin{tabular}{lcc}
\hline Source & Documents & Ranking SCOPUS \\
\hline Journal of Cleaner Production & 109 & $\mathrm{Q} 1$ \\
Resources Conservation and Recycling & 47 & $\mathrm{Q} 1$ \\
Quality-Access to Success & 19 & $\mathrm{Q} 3$ \\
Sustainability (Switzerland) & 14 & $\mathrm{Q} 2$ \\
International Journal of Green Economics & 14 & $\mathrm{Q} 2$ \\
Journal of Industrial Ecology & 12 & $\mathrm{Q} 1$ \\
Ecological Economics & 7 & $\mathrm{Q} 1$ \\
Progress in Industrial Ecology & 7 & $\mathrm{Q} 3$ \\
Technological Forecasting and Social Change & 7 & $\mathrm{Q} 1$ \\
New Biotechnology & 6 & $\mathrm{Q} 1$ \\
Environment, Development and Sustainability & 6 & $\mathrm{Q} 2$ \\
Forest Policy and Economics & 6 & $\mathrm{Q} 1$ \\
Futures & 6 & $\mathrm{Q} 1$ \\
International Journal of Energy Economics and Policy & 6 & $\mathrm{Q} 1$ \\
Business Strategy and the Environment & 5 & $\mathrm{Q} 1$ \\
Journal of Commercial Biotechnology & $\mathrm{Q} 3$ \\
International Environmental Agreements: Politics, Law and Economics & 4 & $\mathrm{Q} 1$ \\
Science Technology and Human Values & 4 & $\mathrm{Q} 1$ \\
Technology in Society & 4 & $\mathrm{Q} 2$ \\
Total & 288 & \\
\hline
\end{tabular}

Separating the publications by selected key words resulted in the CE emerging as the most researched topic with 211 publications, followed by the GE with 164 and the BE with 74 . The CE is the 
concept with the oldest publications, dating back to 2004, and the number of publications on this topic has increased considerably since 2009. The oldest publications on the BE and the GE date back to 2008 and 2009 respectively, with an increase in the number of publications on the GE since 2011 and on the BE since 2013 (Figure 3).

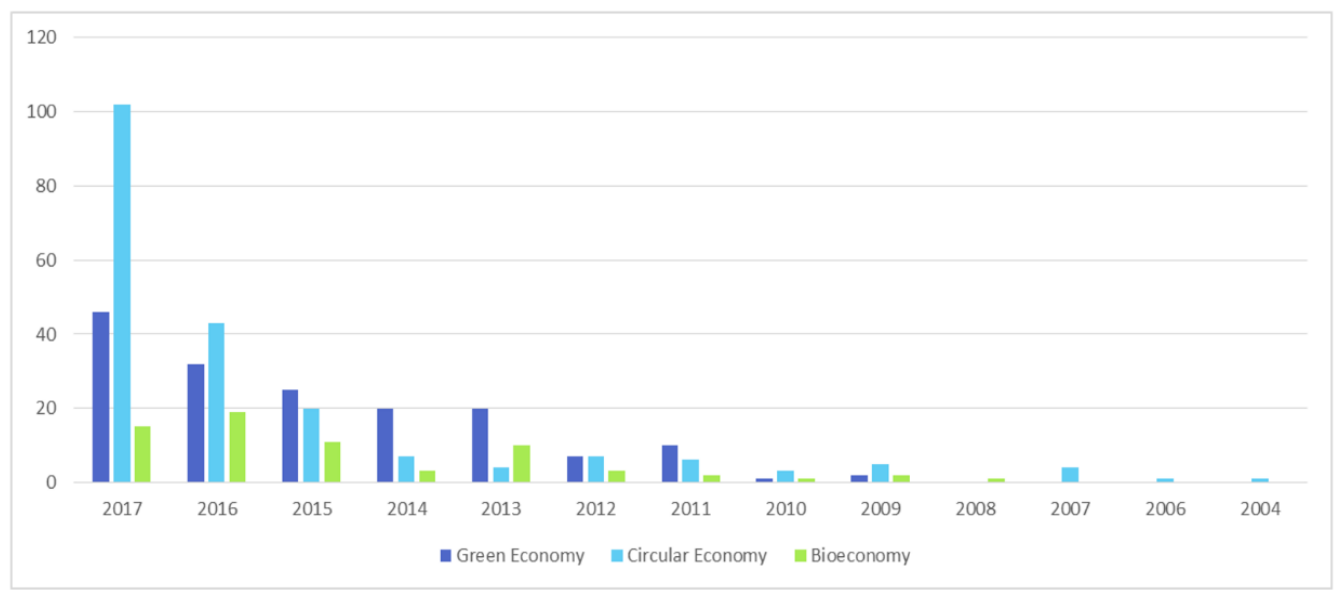

Figure 3. Publications by topic and year.

When the authors' country of affiliation was analysed, the CE was shown to be mainly studied in China and the United Kingdom, followed by the Netherlands and the United States. The United States, Germany, Belgium and Spain were in the leading positions on analysing the BE, and the United States, the United Kingdom, Romania, Russia and Italy appeared most frequently regarding publications on the GE (Figures 4-6).

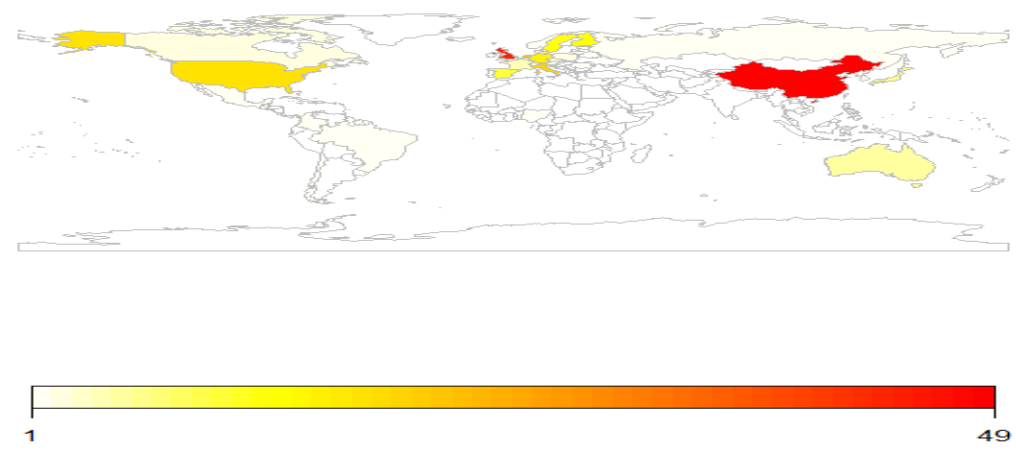

Figure 4. Geographical origin of the literature on the circular economy (CE) according to the affiliation of the authors (number of articles). Software R 3.5.0.
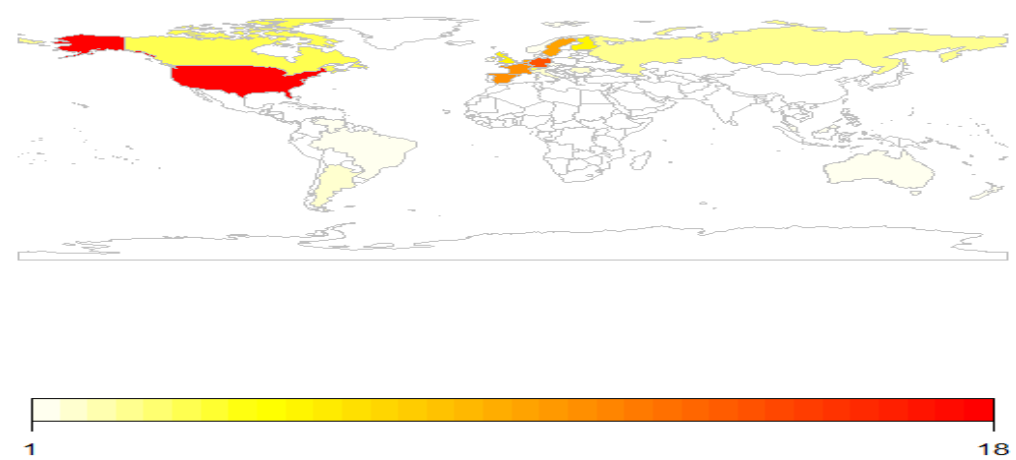

Figure 5. Geographical origin of the literature on the bioeconomy (BE) according to the affiliation of the authors (number of articles). Software R 3.5.0. 


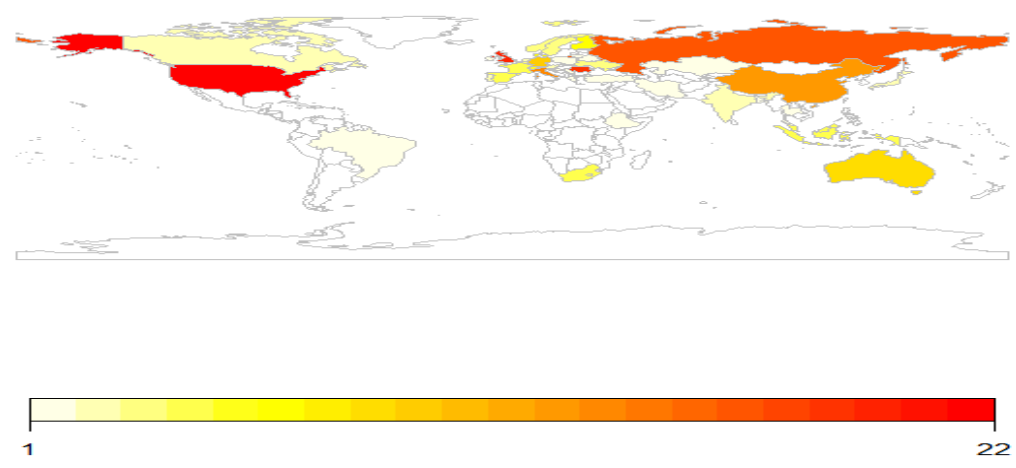

Figure 6. Geographical origin of the literature on the green economy (GE) according to the affiliation of the authors (number of articles). Software R 3.5.0.

An overview of the selected articles indicated that besides the areas of economics, econometrics, finance, business management and accounting they are also concerned with environmental, energy and engineering sciences. When key words were analysed, the following themes were shown to recur: economic and social effects, sustainability, climate change and environmental and sustainable development.

\subsection{Categorisation by Researched Topics}

An analysis of the content of the publications to achieve a categorisation by theme was considered essential to classify the articles and know the main trends in publications, as well as to ease the researcher's task of searching for articles on their topic of interest. Seventeen categories were defined, bearing in mind that such a categorisation can be subjective. Our objective was to propose a classification comprised of a list of categories long enough to be both useful and establish differentiation. These 17 recognized categories are defined in Table 2.

Table 2. Definition of Categories.

\begin{tabular}{ll}
\hline Category & Definition \\
\hline Design or policy analysis & $\begin{array}{l}\text { Including description, analysis and evaluation of policy proposals, } \\
\text { implementation studies, decisions and possible solutions to consider. }\end{array}$ \\
\hline Sectoral application/cluster & $\begin{array}{l}\text { Applications of the studied topics in a specific sector or in a cluster of } \\
\text { companies. Includes analyses of business models, and analyses and evaluation } \\
\text { of management, profits, performance and the behaviour of companies. }\end{array}$ \\
\hline Management Styles & $\begin{array}{l}\text { Design, development and implementation of business models and strategies, } \\
\text { especially at the company or sector level. }\end{array}$ \\
\hline $\begin{array}{l}\text { Small and medium-sized enterprises } \\
\text { (SMEs)/family businesses }\end{array}$ & Applications of these models especially in SMEs or family businesses. \\
\hline Corporate Social Responsibility & Articles focused on corporate social responsibility. \\
\hline Literature review & Literature review articles. \\
\hline Theoretical/conceptual framework & $\begin{array}{l}\text { Works based mainly on the definition of concepts and the theoretical } \\
\text { framework of the topics. }\end{array}$ \\
\hline Products design & Application of sustainability in product design. \\
\hline Life cycle assessment & Life cycle analysis as a tool to evaluate or analyse the impact of products. \\
\hline Consumer behaviour & $\begin{array}{l}\text { Consumer behaviour and preferences regarding aspects such as ecological } \\
\text { products, sustainable production, etc. }\end{array}$ \\
\hline Case study & $\begin{array}{l}\text { Case studies of the concepts applied in companies. Analysis of models, } \\
\text { implementation in companies, economic analysis and operations. }\end{array}$ \\
\hline Innovation & Cases of eco innovation to improve efficiency and sustainability. \\
\hline Education & Educational aspects related to the topics studied here. \\
\hline
\end{tabular}


Table 2. Cont.

\begin{tabular}{ll}
\hline Category & Definition \\
\hline Tourism & Articles focused mainly on sustainable tourism \\
\hline Indicators & Different types of sustainability indicators. \\
\hline Investment & $\begin{array}{l}\text { Decision-making models, risk analysis and investment strategies in these } \\
\text { ecological areas. }\end{array}$ \\
\hline Others & Items that do not correspond to any previous category. \\
\hline
\end{tabular}

Appendix A contains the 449 documents analysed, classified by subject and field. Sixteen different categories concerning the $\mathrm{CE}$ were obtained according to the research topics, $41 \%$ of which were about the first three categories. Regarding the BE, 13 categories were identified, the first four representing $69 \%$ of the publications. The GE articles were classified into 15 categories, with the three most important representing $58 \%$ of the total. When analysing the three topics together, the most important categories identified were "Design or policy analysis" and "Sectoral application/cluster" (Table 3).

Table 3. Categories of publications by topic.

\begin{tabular}{lcccc}
\hline & Circular Economy & Bioeconomy & Green Economy & Total \\
\hline Design or policy analysis & $12 \%$ & $34 \%$ & $34 \%$ & $24 \%$ \\
Sectoral application/cluster & $12 \%$ & $15 \%$ & $15 \%$ & $14 \%$ \\
Management Styles & $17 \%$ & $3 \%$ & $9 \%$ & $11 \%$ \\
Life cycle assessment & $9 \%$ & - & - & $4 \%$ \\
Literature review & $8 \%$ & $4 \%$ & $2 \%$ & $5 \%$ \\
Theoretical/conceptual framework & $7 \%$ & $8 \%$ & $4 \%$ & $6 \%$ \\
Consumer behaviour & $7 \%$ & - & $5 \%$ & $5 \%$ \\
Products design & $5 \%$ & - & - & $2 \%$ \\
Case study & $4 \%$ & $12 \%$ & $4 \%$ & $6 \%$ \\
Innovation & $4 \%$ & $7 \%$ & $5 \%$ & $5 \%$ \\
Indicators & $4 \%$ & $4 \%$ & $3 \%$ & $4 \%$ \\
Education & $2 \%$ & $3 \%$ & $1 \%$ & $3 \%$ \\
Tourism & $1 \%$ & $3 \%$ & $3 \%$ & $3 \%$ \\
Investment & - & $3 \%$ & $1 \%$ & $1 \%$ \\
Corporate Social Responsibility & $2 \%$ & $1 \%$ & $3 \%$ & $3 \%$ \\
SMEs/family businesses & $3 \%$ & $4 \%$ & & $2 \%$ \\
Others & $3 \%$ & - & & $\%$ \\
\hline
\end{tabular}

\subsection{Trends in Publications: Main Research Findings}

In this section, contributions in the most prominent categories are analysed, as are the categories "Case Study" and "Indicators" because of their relevance to the chosen areas. Figure 7 shows the evolution of publications in the categories analysed.

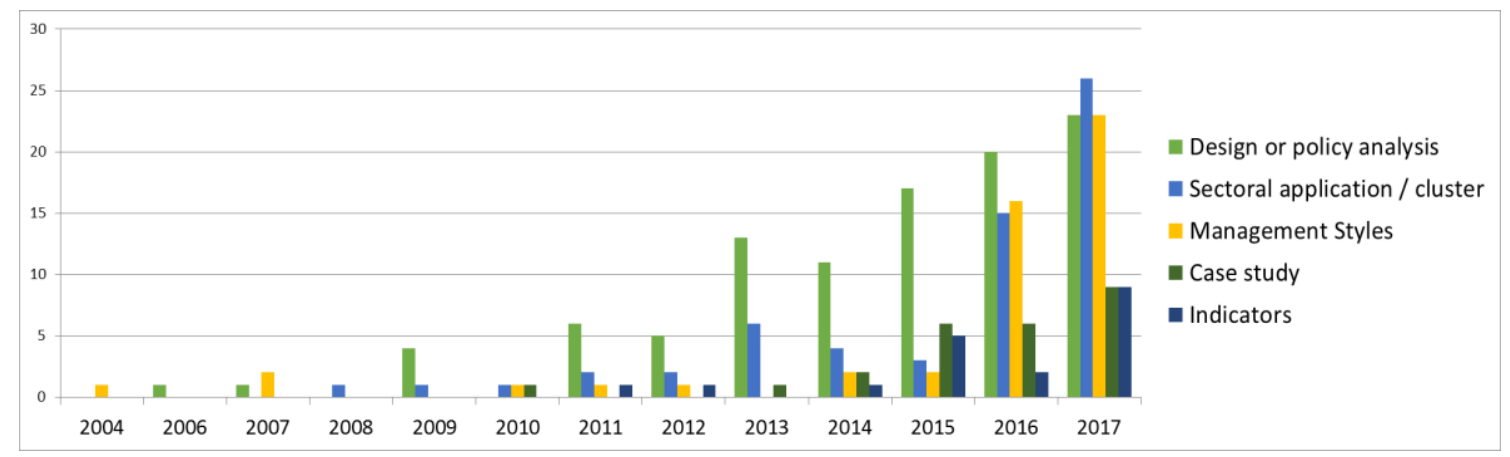

Figure 7. Evolution of main categories. 


\subsubsection{Circular Economy}

In relation to the $\mathrm{CE}$, the categories with most articles are: Management Styles (17\%), Sectoral application/cluster $(12 \%)$ and Design or policy analysis $(12 \%)$, representing $41 \%$ of the articles.

Regarding "Management Styles", two main groups used in other studies can be established: micro and meso [14]. Studies of specific sectors, or those related to industrial symbiosis or eco-industrial parks, are included at the meso level. Studies of specific companies, particularly SMEs and sectors, and especially electronics and electro-domestics companies, are included at the micro level.

Analyses at the meso level account for over $50 \%$ of the total and are mainly applied to Europe and China, and to the food and agriculture, technology and construction sectors. Topics discussed in the food and agriculture sector include: how to incorporate CE management and assessment in the production, consumption and waste stages [14,29-31], impact on agriculture, cost reduction, and increased profitability [32,33]. Analysing the $\mathrm{CE}$ as a business strategy is also applied to the technology and communications sectors [34,35]. As for the electronics and electro-domestics sectors, articles can be found on implementing new business models [36], increasing life cycles or recycling [37,38], and the choice of greener materials [39]. The analysis of the construction sector focuses on waste management $[40,41]$.

Articles on industrial symbiosis or eco-industrial parks focus on the relationship established to generate economic profit for companies, and they analyse how to integrate and manage the CE within their business models [42-45].

Second, with $12 \%$ of publications, was the category "Sectoral application/cluster", $73 \%$ of which referred to China ( $46 \%$ ) and the European Union (27\%). A significant proportion of the articles that refer to China analyse concrete examples of the economic and environmental benefits of opting for industrial symbiosis or transforming into eco-industrial parks. Several articles set out the actions and decisions required for developing the $\mathrm{CE}$ in eco-industrial parks; they also emphasise the importance of evaluating its implementation [46-52]. One study [53] addressing the need for government measures for improved efficiency of resources is worthy of special mention.

Within Europe there is only one article related to industrial symbiosis and eco-parks and it concerns Sweden [54]. There are also publications in Spain [55], Italy [56,57], the United Kingdom [58] and Germany [59]. The focus is mainly on studies related to recycling and waste management, analysing the economic impacts of using the CE. In Italy the positive effects of applying the CE in production and employment are observed in the packaging recycling sector [57] and in charges for waste collection [56]. In Sweden, the need for the recycling sector to find new business models and to set up associations or eco-industrial parks is highlighted [54]. An interesting study [58] quantifies waste generation in the UK by sector using an input-output analysis, finding that construction and extractive industries generate most waste.

Due to the importance of the construction and metal industries in generating waste, several articles are identified related to this subject. In the case of construction, the environmental benefits of applying the CE are shown [60], in addition to the need to improve resource efficiency in the cement industry [59]. In the aluminium industry improvements due to implementing the $\mathrm{CE}$ are analysed [61,62]. Iron and steel require a greater commitment in terms of the CE, especially if the huge quantity of resources and energy used and the contamination generated are taken into account $[63,64]$.

China was also shown to predominate in the third category, "Design or policy analysis", with $46 \%$ of the publications. The research topics in this category refer mainly to correctly implementing CE policies, their durability, evolution and possible evaluation, and government actions such as tax policy applications and regional incentives.

In the articles on China several studies were found $[65,66]$ on implementing a pilot area with the $\mathrm{CE}$ and designing a "green" fiscal policy as the main incentive to promoting a green economy. In [67] the concept of the CE and its implementation in China are analysed, and in [68] existing obstacles are considered. 
In relation to the recycling sector in China, $[69,70]$ conclude that the main governmental means to promote the $\mathrm{CE}$ are tax incentives, encouraging innovation and development and its regulation.

Articles [71,72] analyse regional initiatives in China that have successfully implemented a CE and the challenges they faced in doing so (lack of incentives and financial support and poor public awareness), and they detail ways of meeting these challenges: tax reform, financial assistance and training in CE. These studies help orientate other cities or regions that aim to adopt the CE in their development model.

There is a comparative study on implementing the CE in China and the EU that determines that the Chinese perspective emerges as a response to rapid industrialisation, which has led to increased contamination, waste and use of resources [73]. In Europe, the CE falls within the field of waste and focuses mainly on companies. Although both China and the EU believe that indicators are essential, none have as yet been defined by the European Commission, so China's indicators could potentially be considered by the EU.

On analysing the articles related to the EU it was observed that there is a general analysis of the evolution of environmental policies to mitigate climate change and develop the CE [74]. Existing practices on eco-design are analysed in $[75,76]$ and the conclusion drawn is that there is little research in this field. It is considered that eco-design directives should include more environmental aspects and focus on resource efficiency, and it is recommended that efficiency indicators be established. Within the EU, policy design and analysis were shown to focus mainly on recycling and also on its relationship with ecological design. There is no mention of European countries that have implemented CE strategies, focusing only on EU strategies. Other countries considered in these publications are Australia [77,78], South Korea [79] and Mexico [80].

As we are analysing publications in the field of economics and business management, we consider it appropriate to analyse two of the important categories in the field, "Case study" and "Indicators", which represent only $4 \%$ and $4 \%$ of the publications, respectively.

Within the category "Case Study", we find cases in both China and the EU. The cases in China research implementing $\mathrm{CE}$ as a solution for cleaner production and more sustainable development, providing solutions for problems of resource efficiency, recycling, emissions and seeking economic profits, mainly in the chemical industry [81-83]. However, the cases in Europe mainly focus on the problem of recycling and reusing waste, quantifying the environmental impact of the problem and seeking possible solutions focused on designing specific products and systems [84,85], as mentioned in the previous categories "Design or policy analysis" and "Sectoral application/cluster".

Analysis of the "Indicators" category showed there to be few publications. Some papers have proposed measures to know how the $\mathrm{CE}$ has been implemented in certain circumstances and others measure its performance or impact. China was found to be the first country to use indicators and it was concluded that they require a thorough review to include more social, commercial, symbiosis, and prevention-oriented indicators [86]. Regarding indicators applied to companies, publication [87] must be highlighted in that it proposes a practical model called "Expanding Zero Waste" to measure the results and impacts of commercial circular strategies based on reducing waste. Another article [88] proposes a scale for materials' yield to measure the contribution of a material according to the time it is in use (including restoration and recycling). However, the problem with this indicator is that it is not monetary and therefore does not reflect economic yield. An application specific to plastic waste [89] measures the efficiency of the CE by means of the different treatments applied to plastic as waste depending on its quality.

The importance of measuring circularity lies in the possibility of measuring the effects of the CE in terms of return, job creation and environmental impact. In [90] a possible measure is proposed based on the economic value of the parts of the product. In addition, considering only the environmental aspect, a set of indicators is designed to evaluate the efficiency of specific processes in the CE model (efficiency in the use of resources, waste minimization and conversion), which in this case are applied to the pig industry considering the impact of manure. Three important groups of indicators for CE are 
determined: the water that provides information on the reduction of water, the biofertilizer related to the production of biofertilizer and biogas, which provides information on the reduction of natural gas consumption. Within these groups, the article details nine useful indicators to evaluate the pig manure treatment process. These types of studies are necessary to allow decision makers to evaluate the efficiency of the CE and decide to implement it [91].

\subsubsection{Bioeconomy}

Within the BE most publications are in the category "Design or policy analysis" (34\%) with a large number of studies from the EU (76\%) coinciding with the publication of its Bioeconomy Strategy in 2012.

At the European level, [92] analyses the BE from a political and conceptual perspective, highlighting the opportunities and benefits it offers. Twelve BE strategies are analysed for Europe in general and Sweden, Germany, Finland, Belgium and Holland, specifically, showing that there is a common direction based mainly on research and technological innovation. Also highlighted is the role played at the regional level to foster collaboration between industry and research organisations. Moreover, developing new markets and adopting biological products is considered paramount for the $\mathrm{BE}$ to expand. To this end, government participation is recommended to encourage the consumption of biological products and to raise consumer awareness [9]. Continuing to focus on Europe, [93] analyses the current situation of the BE, the challenges facing the European Commission, and future steps it should consider when revising strategy, emphasising the agri-food, chemical, forestry and sea-based sectors, and continuous investment in research.

The importance of policies that promote a positive impact on the BE is emphasised [94], as is the urgent need to take the economic, social and environmental dimensions of the BE into equal consideration [1].

Different countries' strategies were also analysed. For countries in southern Europe (Spain, Portugal, Italy, Greece and Cyprus), it is proposed that politicians, industry and key players take 10 critical steps to develop a BE and to effectively end the economic crises in these countries [95]. In Germany the current BE situation is analysed with reference to wood and biofuels [96,97].

In Finland there is a study that shows how they focuses on forestry policies and highlights the importance of this sector for developing the BE in this country [98]. Spain is one of the EU countries that has published a BE strategy (2016), the main aim of which is to maintain the BE as an essential part of the economy, placing particular emphasis on research, development and innovation in the area, and public-private collaboration [99].

In [6] BE strategies in the EU, the USA, Canada, Sweden, Finland, Germany and Australia are compared, underlining the need for further research and development and highlighting successful cases of BE as a means of promotion. Environmental and social aspects and the availability of resources are addressed to a limited extent in most strategies.

In the case of Asia, only one publication, related to Malaysia and its BE implementation policy (2012), was found [100]. It must be pointed out that although the United States also implemented a strategic BE in 2012, an insignificant number of studies were carried out on this subject in this country.

Last, in Latin America two publications analysed the possible adoption of BE principles, emphasising the need for more research, innovation and investment in the area [101,102].

The category "Sectoral application/cluster" accounts for 15\% of the publications. Studies applied to agri-food, forestry and bio refineries in Europe (67\%) predominate. At the European level the transition towards the BE is analysed for the cellulose and paper industry, considering the strategic alliances between sectors and the role of policy and regulations as key elements [103]. In the UK the need for further research into bioproducts and related industries was detected [104]. In the case of Holland, the focus is on the use of biomass for producing bioenergy and biochemicals, and the macroeconomic impact in the medium-term is analysed using a computable general equilibrium model and an energy system model. The results show that an increase in the use of biofuels raises GDP and 
added value [105]. Research in Germany also focuses on biorefining and highlights the need to foster integration and coordination through specific policies [106]. In Sweden, the forestry sector is analysed, reviewing policies to direct it towards a BE [107]. Biogas production is also researched and the need to research biorefineries is recognised [108].

Twelve percent of the publications are in the category "Case Study". Remarkably, 78\% of these correspond to Europe and are mainly examples applied to the agri-food sector $[109,110]$ and forestry [111,112].

Within the agro-industry sector organic waste is studied, confirming that its use leads to both lower costs and less environmental impact [113].

In Finland, the BE is most evident in forestry. Socio-economic impacts (employment and income) are analysed showing positive results which could be improved further if new concepts related to the $\mathrm{BE}$ are fostered, thus generating new economic activity [111]. Citizen participation in BE decisions to achieve a more collaborative approach is also analysed [114].

In Brazil, the potential of biomass from sugar cane is studied, identifying its uses and applications and demonstrating that it is a viable alternative to fossil fuels. The need to invest in innovation, promote collaboration between the private sector and research institutions and implement policies to stimulate investment is also established [115].

Last, only $4 \%$ of the articles were related to "Indicators", all published in 2017. In [116] measurement methodologies are analysed and three focus points are determined. The most traditional is to approach the BE as part of GDP and to estimate employment rates. Another focus is to measure the proportion of the bio part of products and services of the BE. A third focus is to take the BE as omnipresent and not associate it with specific sectors. However, other impacts must be considered when measuring the BE: reducing carbon emissions and improving water, soil and biodiversity, health and well-being. In light of this point, the first two approaches would be incomplete while the third, which would be the most suitable, is extremely demanding. It is concluded that measurements of the $\mathrm{BE}$ are still in the early stages and pose a real challenge for the future.

In the $\mathrm{EU}$, one of the methods found to measure the $\mathrm{BE}$ is based on detecting which sectors are either totally or partially related to it and then calculating the income, added value and employment generated by those sectors. Where sectors are partially bioeconomic, a calculation methodology is established to estimate the proportion based on experts' opinion. This analysis is fundamental for developing BE strategies in other EU countries [117].

Another article focuses on analysing the connections between bioeconomy sectors and the rest of the EU economy by using the linear SAM (Social Accounting Matrix) model, using tables specially designed for the BE sector (Bio SAM). The goal is to identify the key sectors potentially related to the BE, which are then considered when formulating policies and taking decisions. The results demonstrate that the BE has not yet reached its full potential in affecting production and creating employment [118].

\subsubsection{Green Economy}

The three most important categories are "Design or policy analysis", "Sectoral application/cluster" and "Management Styles", representing 34\%, 15\% and 9\% of the publications, respectively. The first category mainly considers the GE as a global requirement and investigates the role of government and policy implementation and strategies to achieve the transition to the GE and meet the established sustainable development objectives. The emphasis is on the importance of creating green jobs for an improved labour market. Analysing these publications by country, Asia stands out with almost $50 \%$ of its publications from China and also from Malaysia.

In the case of Asia, in [119] the role of tax instruments in the transition to a GE is analysed, concluding that these measures are being adopted very slowly, which is not helping the transition process. Powerful measures are needed, such as a carbon tax or a tax on natural resources extraction, to boost government income to incentivise the transition to a GE, invest in research, develop cleaner energies, finance ecological projects, and so on. 
In China, the GE model was addressed later than in other countries, although transition has been rapid due to the government adopting the GE as the national development strategy [120]. Its implementation has reduced pressure on the environment and promoted more sustainable industrial development. However, in order to obtain more reliable data, a unified system of indicators [121] must be studied in greater depth. As for existing taxation in China, current laws do not use tax as a tool to prevent or reduce contamination and emissions. For this reason [122] states the need for tax reform with a view to green taxes, the income from which would be used to promote a greener economy.

Malaysia is well on the way to a GE [123], promoting investment in energy efficiency, reutilisation, recycling, training, and innovation in technology and materials. However, there needs to be greater focus on subjects related to the financing, regulation and control of the market to promote the GE in smaller enterprises [124] and to raise general awareness [125].

In Europe, the importance of government intervention to ease the transition to a GE by means of regulation, public investment and contracting, incentives and monitoring is clearly established. The publications mainly focus on incentives to improve natural capital and social equity [126]. The energy sector is seen as the most important to reduce gas emissions and promote renewable energy sources [127]. Given the aforementioned importance of green jobs, several articles affirm that integrating this idea into national policies is essential to moving towards a greener economy [127-130].

In the case of Russia the necessary move from a "brown" to a "green" economy requires more investment in technology, government involvement via legal and economic measures that promote and force public and private enterprises to move towards a more efficient and environmentally-friendly economy, and indicators to measure economic development and social and environmental factors [131]. A study carried out in Switzerland analyses energy efficiency as the cornerstone for a transition to a GE with positive results for GDP and employment [132].

There were also some articles from Africa [133-135], America [136,137] and Australia [138]. Other research relates the GE to developing countries [139-142] where green growth can potentially transform the economy and alleviate poverty. However, this must go hand in hand with suitable policies [140].

There were fewer publications in the category "Sectoral/Cluster application" (15\%). They are from different geographical regions and they focus on the strategies and initiatives that can potentially be taken in different sectors. In [143] it is shown that green initiatives taken by textile companies have a positive effect on competitiveness at the international level due to reduced costs. In the case of the agro-industry sector, implementing the GE at a logistic level is examined with the aim of reducing production and environmental costs, and raising its profile in society [144].

Energy is another important sector in this category. The case of India, whose main source of energy is thermal, which emits many greenhouse gases, highlights the need to promote increased investment in producing clean energy and its efficient use [145]. This sector is also analysed in Russia, stressing the need for innovation, technological improvements and research in the field to be able to improve the sector and make it cleaner [146].

In third place is the category "Management Styles", which represents $9 \%$ of the publications, which are predominately studies on implementing the GE as a strategy in companies, for example proposing management models for companies that want to be "greener" and approach a more sustainable path $[147,148]$. Other applications found are developing a framework to evaluate and select green suppliers [149], guiding best practice to promote the GE and a model for making decisions related to ecological operations [150-152].

If we also analyse the category "Case Studies", we see that these represent only $5 \%$ of the publications, and that they are mainly applied in Europe. Many of the cases attempt to measure the economic impact of the GE, as well as the environmental and social impacts. Several publications also analyse the impact of the GE on creating green jobs $[153,154]$. 
Article [155] focuses on managing packaging waste in Portugal, analysing its economic, environmental and social impact. Environmental benefits are assessed using input-output tables for life cycle and economic impact, demonstrating a significant economic impact and employment generation.

Article [156] presents an ecological business model that encourages companies towards a GE via reducing resources and waste, and improving the quality of life, well-being and health of the community.

Article [157] focuses on analysing case studies of implementing the GE in five European countries, with the aim of pinpointing key achievements, lessons learnt and crucial factors in the success or failure of these projects. The main findings are the need for leadership, negotiation of interests between stakeholders and guaranteeing continued finance.

Last, when analysing the category "Indicators", which represents just $5 \%$ of the publications, articles that analyse the use of indicators to consider the impact of the GE on job creation, indicators of measurement of progress, resource efficiency and economic and environmental indicators must be highlighted.

Considering the importance given to green jobs, research in Romania [158] using sustainability indicators has shown that these have increased and concludes that efforts must continue to be made to maximize the job-creating potential of the green sector.

Regarding sustainability assessment indicators, in [159] a methodology is established which allows companies to assess growth towards a GE, including indicators for economic transformation, progress, well-being, and resource efficiency.

Another proposed methodology to assess the level of GE applied to Rio de Janeiro is to use partial indicators representative of the economic, social and environmental aspects of the most important sectors [160].

Evaluating GE performance has also been applied to cities in China, considering economic growth and protection of the environment and resources. The results show that most cities have performed inefficiently [161].

Implementing "green econometric models" is recommended to assess energy consumption in production process, in conjunction with other sustainable environmental and economic impact criteria [162].

\section{Discussion}

\subsection{Evolution and Geographical Distribution of Publications}

The concepts green economy, circular economy and bioeconomy came into being between the 1970s and the 1990s. However, it was not until the beginning of 2004 that they became popular in the field of economics. In the case of the $\mathrm{CE}$, the number of publications on this topic has increased considerably since 2009, and, based on our analysis of geographical origin, China was shown to be the country where more authors have published on the topic of the CE, influenced by the 2008 passing of a National Circular Economy Law. Following the approval of the EU Action Plan on the circular economy in 2015 [28], publications have also increased considerably and are expected to continue growing in these countries.

As for the BE and the GE, the European Union is the area where most publications have come from, but if we consider single countries the USA is in first position. The increase in publications on the BE from 2013 onwards can be attributed to the publication of the European Bioeconomy Strategy and the US National Bioeconomy Plan, both in 2012. It must be pointed out that although the United States also implemented a strategic BE in 2012, the number of studies carried out in this country is not significant. It is believed that more BE strategies should be implemented and analysed in the United States, Asia and Latin America.

Regarding the GE, the increase stems from 2011 when the United Nations Program "Towards a Green Economy: Pathways to Sustainable Development and Poverty Eradication" was launched. It is 
worth noting that when performing this geographical distribution analysis the information we obtain is skewed towards developed countries, who may appear more active academically in Scopus [10].

\subsection{Interrelation of the Three Concepts}

The joint analysis of the three subjects shows that despite certain differences the common goal is achieving sustainable development. On analysing the overlap between them, 11 articles were found, mainly from the last year of analysis. The results suggest that the concept of GE can be taken as a more general concept, considering that both the $\mathrm{BE}$ and the $\mathrm{CE}$ are components of the GE, while the $\mathrm{CE}$ is the most concrete concept of the three. It could be said that the $\mathrm{CE}$ is not complete without an adequate $\mathrm{BE}$ that addresses, for example, organic waste from agriculture and forestry.

The analysis of the literature shows the evolution of the concepts, noting that the substantial increase of articles has occurred for the GE since 2011. Nevertheless, it is not until 2015 that the articles on $\mathrm{CE}$ and $\mathrm{BE}$ become more frequent, highlighting mainly those related to the $\mathrm{CE}$.

If we consider the last years, we observe a new paradigm shift, which initially focused on a GE in a general way, then focused on waste and the CE and, finally, considered biological resources through the BE. Because of this, since 2017, the CE and the BE have begun to be treated jointly as the circular bioeconomy. For this reason, in October 2018, the European Commission published the update of the European Bioeconomy Strategy: "A sustainable bioeconomy for Europe: strengthening the connection between economy, society and the environment" where it involves both concepts and whose objective is to develop a sustainable and circular bioeconomy that serves society, the environment and the economy of Europe [163]. Also in the same year, the "Andalusian Strategy of Circular Bioeconomy" [164] was published in Spain.

In addition, on the other hand, the importance of focusing on the blue economy and the blue bioeconomy to consider the seas and oceans has been emphasized, but so far there has not been much research work.

This literature review has evidenced the close relationship between the three concepts and their interdependency in maximizing their social, economic and environmental impacts to achieve the goal of a more sustainable world [21]. Currently it can be said that the development of bioeconomy, circular economy and also blue economy policies will contribute significantly to world-scale objectives related to climate change, sustainable development, resource efficiency, waste recycling, and increased economic growth and job opportunities [165].

\subsection{Analysis of Trends in Publications}

Trends in publications point to researchers' recent growing interest in the three concepts, evidenced mainly by publications in the categories "Design or policy analysis", "Management Styles" and "Sectoral/Cluster application". In turn, debating the results of the categories "Case Study" and "Indicators" is fundamental in these fields.

\subsubsection{Design or Policy Analysis}

"Design or policy analysis" is the most analysed category in terms of all three subjects, with a $24 \%$ share of the publications. The existing literature is rich in studies and analyses of implemented policies related to countries where the strategies have been published, in particular in China and in member states of the European Union.

In order to understand them, it is important to consider the articles that analyze and compare the developed strategies. The CE predominates in China and the EU, analyzing, for example, the different strategy approaches, the driving factors and the barriers in their implementation $[73,166]$. In particular, China is one of the countries that focuses most on the $\mathrm{CE}$, having already implemented it in pilot cities, which serve as a benchmark for others. The CE strategy promoted in China, the "Circular Economy Promotion Law" (2008), covers issues of pollution, waste and resources, while that published by the EU, "Closing the Loop-An Action Plan for the Circular Economy" (2015), has a smaller focus on 
waste and resources and its application to businesses. CE policy in China is undoubtedly the most analyzed in the articles $[67,68,167]$. However, no publications on CE policies have been found in European countries.

The EU is more focused on the BE, coinciding with the publication of its Bioeconomy Strategy in 2012, which mainly affects promoting research and innovation. Although it is known that currently, at the global level, there are several specific or related BE published strategies, this review has identified analyses of countries' strategies: Germany [96], Finland [98], Spain [99], and Malaysia [100], which were promoted in 2013, 2014, 2016 and 2012, respectively. For the countries of southern Europe, a recommended action plan is established to encourage the BE in order to improve its economy and help recovery from the crisis [95]. The articles that analyze BE's policies show us that the focus is on Europe, thanks to the BE strategy "Innovating for Sustainable Growth: A Bioeconomy for Europe" (2012). The studies analyzed offer an overview of the BE in Europe, describe its development, the current situation, the challenges and the need to improve in the future $[1,9,92,93,168]$. However, different BE policies are also analyzed worldwide (EU, USA, Canada, Sweden, Finland, Germany and Australia) [6], demonstrating that all agree in focusing mainly on the improvement of the economy and employment, missing a deepening focus on sustainability aspects and availability of resources, as well as in the development of adequate instruments to measure progress.

The GE has a far more global focus, but the investigations stand out mainly in Asia [119], and particularly in China $[120,121,169]$ and Malaysia [123,124]. The articles analyzed show us that GE policies are not usually based on a specific policy, but are often composed of a group of policies that deal with several issues related to the environment. With the exception of China and Malaysia, no specific research on GE policies in other countries has been identified.

In this category, the need for government intervention through regulatory and fiscal policies that incentivise implementing sustainable growth models is highlighted. Analysing policies highlights the need for financing and investment to implement these models. The publications in all three areas also show that there needs to be more research, development and innovation and that public awareness of environmental issues needs to be raised, which requires government financial support and intervention.

Focusing on these subjects means addressing new products and markets, which governments must regulate and promote. Specific legislation is needed to guide and motivate sectors wishing to incorporate these economic models, and to serve as a means to help the transition towards a more sustainable and ecological economy.

The three economic paradigms also highlight the lack of suitable indicators that consider social and environmental factors as well as economic growth. They suggest the need for government intervention to implement standardised data collection methods and provide reliable instruments to measure results. Furthermore, they underline the need for liaison between academics, the private sector, society and the government to work towards achieving the United Nations Sustainable Development Goals and other global policies related to the environment, such as the COP21 Paris Agreement and the Kyoto Protocol.

\subsubsection{Management Styles}

"Management styles" represents $11 \%$ of the publications and these are mainly in the field of the $\mathrm{CE}$, focusing at the micro and meso levels applied in China and the EU.

The articles analysed in this category focus on managing at a business and industry level and incorporating these models, which is why there are a large number of articles that analyse possible CE, GE or BE strategies, seeking new business models that can potentially generate economic, social and environmental benefits for businesses. These models are analysed and applied in different sectors, principally eco-industrial parks, electronics and the food industry. There are some proposals for practical guidelines for correctly implementing models, decision-making and later analysis. Their main 
contribution is motivational, but they also prepare and facilitate the transition of businesses that are seeking cleaner and more sustainable production.

\subsubsection{Sectoral Application/Cluster}

This category represents $14 \%$ of the publications and the results show that the main application of the $\mathrm{CE}$ in China is in eco-industrial parks, focusing mainly on the economic and environmental benefits. Only one study was found for eco-industrial parks in the EU, demonstrating that China is at a more advanced level of implementation regarding the CE thanks to its 2008 strategy, while the European Union did not launch theirs until 2015.

Both the BE and the GE focus on the food industry, forestry and energy, analysing the economic scope and looking for more sustainability, economic growth, added value, productivity and competitiveness.

These studies are important as they can be used as references for constructing and managing new business models, formulating relevant policies and motivating companies to implement them. The publications analysed in this category also stress the importance of government intervention to motivate businesses and coordinate with the private sector and society, and the need for greater investment to encourage research centred on practical methodological aspects to apply to each sector.

\subsubsection{Case Study}

These represent only represent $6 \%$ of the publications and are mainly in Europe and China. For the GE, the studies analysed focus on the impact of creating green jobs, although there are also cases that analyse the social, environmental and economic impact and the application of business models backed by the GE.

For the BE, the cases are centred on the food industry and forestry, mainly analysing possible alternative applications with a lower environmental impact and cost.

For the CE, cases applied in China are more comprehensive, considering the overall impact environmentally, economically and socially, while cases applied in Europe mainly focus on the environmental impact of recycling and waste.

The analysis of the case studies confirms the conclusions drawn in the other categories, for example, the need for financing and investment for their implementation, more research, and more cases implemented that promote the transition and allow for obtaining better economic results and higher employment.

\subsubsection{Indicators}

"Indicators" represents $4 \%$ of the publications, which corroborates the conclusion of the category on analysing policies in the sense that they are very few in number.

In the case of the $\mathrm{CE}$, the indicators analysed focus on measuring its implementation and evolution. However, no publications were found in this category that analyse the social and economic impact of CE implementation.

The GE is the area that focuses most on developing and implementing indicators that consider the economic, social and environmental impacts, placing great emphasis on analysing the creation of green jobs.

The BE, despite very little research found on indicators, has attempted a mainly economic analysis of its implementation, but this is not reliable as there are no suitable databases available.

As can be seen, there is still a long way to go in terms of measurement. For the three fields, the scarcity of publications and their analysis determine the need for a thorough revision of existing indicators and the development of new ones that can adequately measure social, economic and environmental fields globally. 


\section{Conclusions, Future Lines of Research and Limitations of the Study}

During the last decade, the concepts BE, CE and GE and their relation to the goals directed at developing a sustainable economy have stimulated great interest at the political, academic, social and business levels. However, on analysing the literature, it was observed that none of the literature reviews examined focused on the field of economic and business management.

To this effect, a systematic literature review of the concepts BE, CE and GE in the field of economics and business management was carried out, using 449 publications selected from the Scopus database.

The CE represents $47 \%$ of these publications, followed by the GE with $37 \%$ and the BE with $16 \%$. The importance of the topics analysed has increased remarkably in recent years. Eighty-seven per cent of the selected publications have been published since 2013 and 59\% of these in the last two years, 2016 and 2017. The countries with most publications are mainly European, with the UK, Germany, Italy, Sweden, Spain and Finland leading the way, but with a significant number of publications from China and the USA.

Regarding the most important journals for the subjects studied, the first five journals in order of the number of publications are Journal of Cleaner Production; Resources, Conservation and Recycling; Quality-Access to Success; Sustainability; and, International Journal of Green Economics. Together, these represent $45 \%$ of the publications.

The results show that the three concepts vary in their geographical distribution. The CE predominates in China and the EU. The BE leads in Europe but has little impact in Asia and the USA. The GE has a far more global focus. These results are largely due to the different public policies implemented by respective governments. The political documents show us that there are several strategies focused on these issues in many countries, therefore, this analysis leads us to the conclusion that it is still necessary to continue with the studies and comparisons of these at the academic level.

An added value of this article is the categorization by themes, obtaining 17 categories. This analysis allows us to identify "Design or policy analysis" as the most prominent topic, represented by $24 \%$ of the publications and included within the three most important categories of each concept. In second place is the category "Sectoral application/cluster" with $14 \%$ of the publications. Next, is the category "Management Styles" represented by $11 \%$ of the publications, particularly on the CE and the GE.

This analysis has allowed us to identify publications related to implemented policies, strategies, case studies and the business models of companies that seek a more sustainable path. This fact is significant, since the exploration of these topics, as well as government regulations and policies, will help organisations see where new opportunities lie, evaluate the impact of implementing them and move towards objectives to approach a more sustainable system. However, when carrying out this categorisation it was seen that there is still a long way to go in terms of business implementation and evaluation of the economic measurement of the impacts. Clear examples are the few works on case studies and indicators found. For these reasons sectorial applications and case studies must be investigated in greater depth, as must the analysis of their socioeconomic impact.

If the aim is progress in achieving sustainable development goals, the concepts mentioned, which propose solutions to produce more cleanly without generating waste or gas emissions using materials and resources efficiently and respecting nature, must not only be known but also applied. For this, these concepts should be disseminated and business decision-makers encouraged to focus on applying GE approaches, such as the $\mathrm{CE}$ and the $\mathrm{BE}$.

Several publications conclude that greater collaboration is required amongst academics, companies and government. In Europe there are currently two platforms developed by the European Commission that aim to exchange, interact and share knowledge and information in a "virtual meeting place" for stakeholders across Europe. These platforms are the Bioeconomy Knowledge Centre and the European Circular Economy Stakeholder Platform. It is hoped that these can help disseminate science on these issues, as well as unify concepts and methodologies that can be applied to implement and 
evaluate them. Nonetheless, we are also convinced that this review is a great contribution because it will serve as encouragement and a guide for researchers interested in selecting articles.

In view of the results obtained, we consider that a future line of research is to look for different measures to help entrepreneurs to implement cleaner production, minimising emissions and simultaneously raising competitiveness. Moreover, another future line could be to better analyse the most appropriate indicators and to establish homogeneous database criteria to be applied in different situations and countries. This would allow for accurately evaluating the different strategies promoted.

As concluded, coordination between all stakeholders is essential. For this reason, another line of research could be to find the most appropriate way to disseminate this theoretical knowledge, to promote the exchange of information between companies and to describe experiences from different parts of the world and varied institutions to broaden knowledge and increase collaboration on the studied topics. In particular, it would be interesting to analyse the corporate information of those companies that incorporate new management strategies related to these issues, to motivate and encourage other companies to take these models as references.

Considering the $\mathrm{BE}$ as the topic with the fewest publications related to this field, most of which refer to the European Union, we believe that future research could focus on studying the BE in the field of economics, considering both Asian countries that are applying policies or strategies and America.

We have observed that the term blue economy has emerged to complement the concept of green economy, with the goal of managing the oceans. Within this concept we also find blue bioeconomy, based on the part of the blue economy that uses renewable biological resources from the sea, for example, fish, seaweed and microorganisms to produce food, materials and energy. Both are recent concepts in the academic literature, but given the importance of the seas and oceans, a future line of research should be to analyse these concepts and their inter-relationships in greater depth.

Finally, several limitations of our work need to be considered. The first is the use of just one database (Scopus), although we justify this because it contains more publications and journals than the Web of Science and includes different, useful tools for more detailed descriptive analyses. Second, the categorisation proposed here took mainly academic articles and books or book chapters into account, but there are also contributions published in the form of reports and other types of documents. Moreover, the researcher's subjective evaluation of the articles when determining the areas and their classification must be considered. Furthermore, as only the most important categories have been analysed in depth not all the articles of the literature review have been cited. They are, however, classified in detailed in Appendix A.

Author Contributions: L.P. and A.T. had the idea for the paper. L.P. and V.F.G. carried out the literature review. V.F.G., L.P. and A.T. wrote the introduction, methodology, results, discussion, and conclusions. V.F.G. created all the tables. All the authors read and approved the final manuscript.

Funding: This project has received funding from the European Union's Horizon 2020 research and innovation programme under the Marie Skłodowska-Curie grant agreement No. 713679 and from the Universitat Rovira i Virgili (URV).

Conflicts of Interest: The authors declare no conflict of interest. Those funding the study had no role in its design, in the collection, analyses or interpretation of data, in the writing of the manuscript or in the decision to publish the results. 


\section{Appendix A}

Table A1. Publications on the CE by categories.

\begin{tabular}{|c|c|c|}
\hline Categories & Journals & Authors/Year of Publication \\
\hline \multirow{13}{*}{$\begin{array}{l}\text { Design or } \\
\text { policy } \\
\text { analysis }\end{array}$} & Asian Business and Management & Mathews et al., 2011 \\
\hline & Asian Social Science & Sun 2013 \\
\hline & Comparative Economic Research & Wysokińska 2016 \\
\hline & Handbook of Contemporary China & Lee et al., 2011 \\
\hline & International Journal of Production Economics & Liu et al., 2012 \\
\hline & Journal of Cleaner Production & $\begin{array}{l}\text { Silva et al., 2015; Aguiñaga et al., 2016; Dalhammar et al., 2016; Tsiliyannis et al., 2016; } \\
\text { Golev and Corder 2016; Bundgaard et al., 2017; Guo et al., 2017 }\end{array}$ \\
\hline & Journal of Industrial Ecology & McDowall et al., 2017 \\
\hline & Journal of Material Cycles and Waste Management & Yong 2017 \\
\hline & Marine Policy & Raubenheimer and McIlgorm, A. 2017 \\
\hline & Resources Conservation And Recycling & $\begin{array}{l}\text { Mo et al., 2009; Wübbeke and Heroth 2014; Manomaivibool and Hong 2014; Jiménez-Rivero } \\
\text { and García-Navarro 2017; Ranta et al., 2017; Jiao and Boons 2017; Cobo et al., 2017; }\end{array}$ \\
\hline & Taking Stock of Industrial Ecology & Hill 2015 \\
\hline & Waste Management & Geng et al., 2009 \\
\hline & Journal of Wuhan University of Technology & Zhu 2006 \\
\hline \multirow{7}{*}{$\begin{array}{c}\text { Sectorial } \\
\text { application/ } \\
\text { cluster }\end{array}$} & $\begin{array}{l}\text { Environmental Engineering and Management } \\
\text { Journal }\end{array}$ & Bartolacci et al., 2017 \\
\hline & Journal of Industrial Ecology & Chen et al., 2012; Pagotto and Halog 2016; Zink et al., 2017 \\
\hline & Science of the Total Environment & Noya et al., 2017 \\
\hline & Waste Management & Salemdeeb et al., 2016 \\
\hline & Environment, Development and Sustainability & Zhao et al., 2017 \\
\hline & International Economics and Economic Policy & Winning et al., 2017 \\
\hline & International Journal of Production Economics & Nasir et al., 2017 \\
\hline
\end{tabular}


Table A1. Cont.

\begin{tabular}{|c|c|c|}
\hline Categories & Journals & Authors/Year of Publication \\
\hline & $\begin{array}{l}\text { Journal of Advanced Research in Law and } \\
\text { Economics }\end{array}$ & Beccarello and Di Foggia 2016 \\
\hline & Journal Of Cleaner Production & $\begin{array}{l}\text { Shi et al., 2010; Hu et al., 2011; Dong et al., 2013; Yu et al., 2014; Ma et al., 2014; } \\
\text { Guo et al., 2016; Supino et al., 2016; Zhao and Guo 2017; Han et al., 2017; Wang et al., } 2017\end{array}$ \\
\hline & Resources Conservation And Recycling & $\begin{array}{l}\text { Liu and Bai 2014; Krystofik et al., 2017; Saidani et al., 2017; Aid et al., 2017; Hu et al., 2017; } \\
\text { Zhang et al., } 2011\end{array}$ \\
\hline \multirow{4}{*}{ Case study } & Journal Of Cleaner Production & $\begin{array}{l}\text { Li and Ma 2015; Ma et al., 2015; Richter and Koppejan 2016; De los Rios and Charnley 2017; } \\
\text { Deviatkin et al., } 2017\end{array}$ \\
\hline & Resources Conservation And Recycling & Liu et al., 2017; Krystofik and Gaustad 2017 \\
\hline & Taking Stock of Industrial Ecology & McIntyre and Ortiz 2015 \\
\hline & Thunderbird International Business Review & Rattalino 2017 \\
\hline \multirow{4}{*}{$\begin{array}{l}\text { Consumer } \\
\text { behaviour }\end{array}$} & Business Strategy and the Environment & Hazen et al., 2017 \\
\hline & Futures & Hobson and Lynch 2016 \\
\hline & Journal Of Cleaner Production & $\begin{array}{l}\text { Liu et al., 2009; Miliute-Plepiene and Plepys 2015; Van Weelden et al., 2016; } \\
\text { Mondéjar-Jiménez et al., 2016; Zorpas et al., 2016; Gu et al., 2017; Guo et al., 2017; } \\
\text { Mugge et al., 2017; Atlason et al., } 2017\end{array}$ \\
\hline & Resources Conservation And Recycling & Xue et al., 2010; Favot et al., 2017; Zhong and Pearce 2018 \\
\hline
\end{tabular}


Table A1. Cont.

\begin{tabular}{|c|c|c|}
\hline Categories & Journals & Authors/Year of Publication \\
\hline \multirow{6}{*}{$\begin{array}{c}\text { SMEs/family } \\
\text { businesses }\end{array}$} & Journal of Industrial Engineering and Management & Ormazabal et al., 2016 \\
\hline & Business History & Norris 2017 \\
\hline & Journal Of Cleaner Production & Franco 2017 \\
\hline & Resources Conservation And Recycling & Singh et al., 2017 \\
\hline & Sustainability (Switzerland) & Zamfir et al., 2017; Rizos et al., 2016 \\
\hline & Thunderbird International Business Review & Goyal et al., 2016 \\
\hline \multirow{11}{*}{$\begin{array}{l}\text { Management } \\
\text { Styles }\end{array}$} & Journal of Economic Policy Reform & Yujing and Huihuang 2007 \\
\hline & $\begin{array}{l}\text { Environmental Engineering and } \\
\text { Management Journal }\end{array}$ & Gnoni et al., 2017 \\
\hline & GAIA & Wieser 2016 \\
\hline & Journal Of Cleaner Production & $\begin{array}{l}\text { Park et al., 2010; Abu-Ghunmi et al., 2016; Kuznetsova et al., 2016; Iacovidou et al., 2017; } \\
\text { Urbinati et al., 2017; Zhou et al., 2017; Parajuly and Wenzel 2017; Densley Tingley et al., } \\
\text { 2017; Tecchio et al., 2017; De Almeida et al., 2017; Busch et al., 2017; Zeng et al., 2017; } \\
\text { Jiménez-Rivero and García-Navarro } 2018\end{array}$ \\
\hline & Journal of industrial ecology & Zhu et al., 2011; Niero et al., 2017 \\
\hline & $\begin{array}{l}\text { Logistics and Supply Chain Innovation: Bridging } \\
\text { the Gap between Theory and Practice }\end{array}$ & Zijm and Klumpp 2015 \\
\hline & $\begin{array}{l}\text { Procedia Environmental Science, Engineering } \\
\text { and Management }\end{array}$ & Albino and Fraccascia 2015; Fraccascia et al., 2016 \\
\hline & Progress in Industrial Ecology & Strebel and Posch 2004 \\
\hline & Resources Conservation And Recycling & $\begin{array}{l}\text { Wen et al., 2007; Maaß and Grundmann 2016; Viani et al., 2016; Ng et al., 2016; Witjes and } \\
\text { Lozano 2016; Kuisma and Kahiluoto 2017; Whalen et al., 2017; Martín Gómez et al., 2017; } \\
\text { Kane et al., 2017; Li and Hu 2017; Huang et al., 2018; Gómez et al., 2017; Kane et al., } 2017\end{array}$ \\
\hline & Sustainability (Switzerland) & Jurgilevich et al., 2016 \\
\hline & Technological Forecasting and Social Change & Despeisse et al., 2017 \\
\hline
\end{tabular}


Table A1. Cont.

\begin{tabular}{|c|c|c|}
\hline Categories & Journals & Authors/Year of Publication \\
\hline \multirow{4}{*}{$\begin{array}{c}\text { Corporate } \\
\text { Social } \\
\text { Responsibility }\end{array}$} & $\begin{array}{l}\text { Corporate Social Responsibility and } \\
\text { Environmental Management }\end{array}$ & Kuo et al., 2012 \\
\hline & Environment, Development and Sustainability & Kopnina 2017 \\
\hline & Futures & Mathews 2011 \\
\hline & Journal of Cleaner Production & Sihvonen and Partanen 2017; Weissbrod and Bocken 2017 \\
\hline \multirow{4}{*}{$\begin{array}{c}\text { Product } \\
\text { design }\end{array}$} & Industrial Marketing Management & Spring and Araujo 2017 \\
\hline & International Journal of Production Research & van Loon et al., 2017 \\
\hline & Journal Of Cleaner Production & $\begin{array}{l}\text { Bakker et al., 2014; Smol et al., 2015; Sabaghi et al., 2015; Ferreiro-Cabello et al., 2016; Singh } \\
\text { and Ordoñez 2016; Sommerhuber et al., 2016; Ziyani et al., } 2017\end{array}$ \\
\hline & Resources Conservation And Recycling & Vanegas et al., 2017; Akanbi et al., 2018 \\
\hline \multirow{5}{*}{ Education } & Journal Of Cleaner Production & Kılkış 2018 \\
\hline & Journal of industrial ecology & Geng et al., 2009 \\
\hline & Local Economy & Andrews 2015 \\
\hline & Resources Conservation And Recycling & Whalen et al., 2017 \\
\hline & Taking Stock of Industrial Ecology & Chertow and Park 2015 \\
\hline \multirow{7}{*}{$\begin{array}{l}\text { Life cycle } \\
\text { assessment }\end{array}$} & $\begin{array}{l}\text { International Journal of Product } \\
\text { Lifecycle Management }\end{array}$ & Portillo-Barco and Charnley 2015 \\
\hline & Journal Of Cleaner Production & $\begin{array}{l}\text { Deviatkin et al., 2016; Low et al., 2016; Cooper et al., 2017; Cong et al., 2017; Daddi et al., } \\
\text { 2017; Oldfield et al., 2017; Oldfield et al., } 2018\end{array}$ \\
\hline & Journal of industrial ecology & Mattila et al., 2012; Hass et al., 2015 \\
\hline & Marine Policy & Gilbert et al., 2017 \\
\hline & Omega (United Kingdom) & Genovese et al., 2017 \\
\hline & Resources Conservation And Recycling & $\begin{array}{l}\text { Sommerhuber et al., 2017; Miatto et al., 2017; Pauliuk et al., 2017; Lausselet et al., 2017; } \\
\text { Zeng et al., } 2017\end{array}$ \\
\hline & Taking Stock of Industrial Ecology & Stahel and Clift 2015; Moriguchi and Hashimoto 2015 \\
\hline
\end{tabular}


Table A1. Cont.

\begin{tabular}{|c|c|c|}
\hline Categories & Journals & Authors/Year of Publication \\
\hline \multirow{3}{*}{ Indicators } & Journal Of Cleaner Production & Geng et al., 2012; Franklin-Johnson et al., 2016; Adibi et al., 2017; Veleva et al., 2017 \\
\hline & Journal of Industrial Ecology & Linder et al., 2017 \\
\hline & Resources Conservation And Recycling & Huysman et al., 2017; Di Maio et al., 2017 \\
\hline \multirow{7}{*}{ Innovation } & Business Strategy and the Environment & Linder and Williander 2017 \\
\hline & Foresight and STI Governance & Hojnik et al., 2017 \\
\hline & International Economics and Economic Policy & Kemp et al., 2017 \\
\hline & Journal Of Cleaner Production & Matus et al., 2012; Scheel 2016; Novais et al., 2017 \\
\hline & $\begin{array}{l}\text { The Automobile Revolution: Towards a New } \\
\text { Electro-Mobility Paradigm }\end{array}$ & Fournier 2016 \\
\hline & The Handbook of Service Innovation & Roos and Agarwal 2015 \\
\hline & Vlakna a Textil & Aneja et al., 2016 \\
\hline \multirow{12}{*}{$\begin{array}{l}\text { Theoretical/ } \\
\text { conceptual } \\
\text { framework }\end{array}$} & Environment, Development and Sustainability & Kopnina 2015; Koop and van Leeuwen 2017 \\
\hline & Innovation & Balasescu and Seguin 2017 \\
\hline & $\begin{array}{l}\text { International Journal of Innovation and } \\
\text { Sustainable Development }\end{array}$ & Webster 2007 \\
\hline & Journal of Business Ethics & Murray et al., 2017 \\
\hline & Journal Of Cleaner Production & Fischer and Pascucci 2017; Iacovidou et al., 2017 \\
\hline & Journal of industrial ecology & Chertow and Ehrenfeld 2012; Yuan et al., 2016 \\
\hline & Prakseologia & Qiao 2013 \\
\hline & Resources Conservation And Recycling & Kirchherr et al., 2017 \\
\hline & Systems Research and Behavioral Science & Chen 2009 \\
\hline & Technological Forecasting and Social Change & Jabbour et al., 2017 \\
\hline & Thunderbird International Business Review & Esposito et al., 2017 \\
\hline & WSEAS Transactions on Business and Economics & Kralj et al., 2017 \\
\hline
\end{tabular}


Table A1. Cont.

\begin{tabular}{|c|c|c|}
\hline Categories & Journals & Authors/Year of Publication \\
\hline \multirow{4}{*}{ Others } & Bio-based and Applied Economics & Vollar et al., 2016 \\
\hline & Journal Of Cleaner Production & Cohen and Muñoz 2016; Mohamed Sultan et al., 2017 \\
\hline & Resources Conservation And Recycling & Machacek et al., 2015; Steuer et al., 2018 \\
\hline & Technology in Society & Fox 2016 \\
\hline \multirow{7}{*}{$\begin{array}{l}\text { Literature } \\
\text { review }\end{array}$} & $\begin{array}{l}\text { International Journal of Operations and } \\
\text { Production Management }\end{array}$ & Smart et al., 2017 \\
\hline & $\begin{array}{l}\text { International Journal of Technology Management } \\
\text { and Sustainable Development }\end{array}$ & Barrie et al., 2017 \\
\hline & Journal Of Cleaner Production & $\begin{array}{l}\text { Su et al., 2013; Jiao and Boons 2014; Ghisellini et al., 2016; Lieder and Rashid 2016; } \\
\text { Geissdoerfer et al., 2017; Elia et al., 2017; Pomponi and Moncaster 2017; } \\
\text { Saavedra et al., } 2018\end{array}$ \\
\hline & Organization and Environment & Walls and Paquin 2015 \\
\hline & Renewable and Sustainable Energy Reviews & Winans et al., 2017 \\
\hline & Resources Conservation And Recycling & Burlakovs et al., 2017 \\
\hline & Sustainability (Switzerland) & Lewandowski 2016; Masi et al., 2017 \\
\hline \multirow{2}{*}{ Tourism } & Aestimum & Girard and Nocca 2017 \\
\hline & Quality-Access to Success & Giurea et al., 2017 \\
\hline
\end{tabular}


Table A2. Publications on the BE by categories.

\begin{tabular}{|c|c|c|}
\hline Categories & Journals & Authors/Year of Publication \\
\hline $\begin{array}{l}\text { Design } \\
\text { or policy } \\
\text { analysis }\end{array}$ & $\begin{array}{l}\text { Academy of Strategic Management Journal } \\
\text { Agricultural Economics (United Kingdom) } \\
\text { Foresight } \\
\text { Forest Policy and Economics } \\
\text { Futures } \\
\text { German Journal of Agricultural Economics } \\
\text { Intelligent Systems in Accounting, Finance and Management } \\
\text { Journal Of Cleaner Production } \\
\text { Journal of Commercial Biotechnology } \\
\text { Law and Agroecology: A Transdisciplinary Dialogue } \\
\text { New Biotechnology } \\
\text { New Medit } \\
\text { Sustainability (Switzerland) } \\
\text { Technology Analysis and Strategic Management } \\
\text { Technology in Society }\end{array}$ & $\begin{array}{l}\text { Kasatovaa et al., } 2016 \\
\text { Swinnen and Weersink 2013; Zilberman et al., } 2013 \\
\text { Grebenyuk and Ravin } 2017 \\
\text { Kröger and Raitio } 2017 \\
\text { Sisto et al., } 2016 \\
\text { Zilberman et al., 2015; Pannicke et al., 2015; Puttkammer and Grethe } 2015 \\
\text { Jaffé } 2015 \\
\text { Ramcilovic-Suominen and Pülzl 2016; Blumberga et al., 2016; Koukios et al., } 2016 . \\
\text { Kamal and Dir } 2015 \\
\text { Koukios } 2015 \\
\text { Sasson and Malpica 2018; Bell et al., 2018; Lainez et al., 2018; Patermann and Aguilar } 2018 \\
\text { Padella and Finco 2009 } \\
\text { Staffas et al., 2013; McCormick and Kautto 2013; De Besi and McCormick 2015. } \\
\text { Wield 2013 } \\
\text { Arancibia 2013 }\end{array}$ \\
\hline $\begin{array}{l}\text { Sectorial } \\
\text { application/ } \\
\text { cluster }\end{array}$ & $\begin{array}{l}\text { Biofuels, Bioproducts and Biorefining } \\
\text { Biomass and Bioenergy } \\
\text { AgBioForum } \\
\text { Economic Development Quarterly } \\
\text { Forest Policy and Economics } \\
\text { Futures } \\
\text { Global Bioethanol: Evolution, Risks, and Uncertainties } \\
\text { International Business Management } \\
\text { Journal Of Cleaner Production } \\
\text { Technological and Institutional Innovations for Marginalized } \\
\text { Smallholders in Agricultural Development }\end{array}$ & $\begin{array}{l}\text { Jenkins } 2008 \\
\text { van Meijl et al., } 2018 \\
\text { McFadden and Miranowski } 2016 \\
\text { Low and Isserman } 2009 \\
\text { Johansson } 2016 \\
\text { Toppinen et al., } 2017 \\
\text { Araújo } 2016 \\
\text { Tatuev et al., } 2016 \\
\text { Hagman et al., 2016; Giurca and Späth } 2017 \\
\text { Virchow et al., } 2016\end{array}$ \\
\hline Case study & $\begin{array}{l}\text { Environment, Development and Sustainability } \\
\text { Forest Policy and Economics } \\
\text { International Journal of Innovation and } \\
\text { Technology Management } \\
\text { Journal Of Cleaner Production } \\
\text { Journal of Commercial Biotechnology } \\
\text { Science and Engineering Ethics }\end{array}$ & $\begin{array}{l}\text { Lehtonen and Okkonen 2013; Ravera et al., } 2014 \\
\text { Heinonen et al., } 2017 \\
\text { Golembiewski et al., } 2015 \\
\text { Pergola et al., 2016; Scheiterle et al., 2016; Mustalahti } 2017 \\
\text { Harvey } 2010 \\
\text { Vochozka et al., } 2017\end{array}$ \\
\hline
\end{tabular}


Table A2. Cont.

\begin{tabular}{|c|c|c|}
\hline Categories & Journals & Authors/Year of Publication \\
\hline $\begin{array}{c}\text { Corporate } \\
\text { Social } \\
\text { Responsibility }\end{array}$ & Forest Policy and Economics & Pätäri et al., 2017 \\
\hline $\begin{array}{l}\text { SMEs/family } \\
\text { businesses }\end{array}$ & $\begin{array}{l}\text { New Biotechnology } \\
\text { Journal of Commercial Biotechnology } \\
\text { New Biotechnology }\end{array}$ & $\begin{array}{l}\text { Egea et al., } 2018 \\
\text { Festel et al., } 2012 \\
\text { Mengal et al., } 2018\end{array}$ \\
\hline $\begin{array}{l}\text { Management } \\
\text { Styles }\end{array}$ & $\begin{array}{l}\text { Journal Of Cleaner Production } \\
\text { Science Technology and Human Values }\end{array}$ & $\begin{array}{l}\text { Aquilani et al., } 2016 \\
\text { Birch } 2017\end{array}$ \\
\hline Education & $\begin{array}{l}\text { International Journal of Innovation Management } \\
\text { Journal of Commercial Biotechnology }\end{array}$ & $\begin{array}{l}\text { Festel } 2015 \\
\text { Festel and Rittershaus } 2014\end{array}$ \\
\hline Indicators & $\begin{array}{l}\text { Annual Review of Resource Economics } \\
\text { Bio-based and Applied Economics } \\
\text { Sustainability (Switzerland) }\end{array}$ & $\begin{array}{l}\text { Wesseler and Von Braun } 2017 \\
\text { Ronzon et al., } 2017 \\
\text { Fuentes-Saguar et al., } 2017\end{array}$ \\
\hline Innovation & $\begin{array}{l}\text { Journal Of Cleaner Production } \\
\text { Journal of the Knowledge Economy } \\
\text { Science Technology and Human Values } \\
\text { Technology in Society }\end{array}$ & $\begin{array}{l}\text { Egelyng et al., 2016; Purkus et al., } 2016 \\
\text { Grundel and Dahlström } 2016 \\
\text { Morrison and Cornips } 2012 \\
\text { Reis-Castro and Hendrickx } 2013\end{array}$ \\
\hline Investment & $\begin{array}{l}\text { Biofuels, Bioproducts and Biorefining } \\
\text { Journal of Commercial Biotechnology }\end{array}$ & $\begin{array}{l}\text { Abbati de Assis et al., } 2017 \\
\text { Festel and Rammer } 2015\end{array}$ \\
\hline $\begin{array}{l}\text { Theoretical/ } \\
\text { conceptual } \\
\text { framework }\end{array}$ & $\begin{array}{l}\text { AgBioForum } \\
\text { Agricultural Economics (United Kingdom) } \\
\text { International Food and Agribusiness Management Review } \\
\text { Quality-Access to Success } \\
\text { Science Technology and Human Values }\end{array}$ & $\begin{array}{l}\text { Zilberman and Kim } 2011 \\
\text { Swinnen and Riera } 2013 \\
\text { Boehlje and Bröring } 2011 \\
\text { Bran } 2017 \\
\text { Birch and Tyfield 2013; Goven and Pavone } 2015\end{array}$ \\
\hline $\begin{array}{l}\text { Literature } \\
\text { review }\end{array}$ & $\begin{array}{l}\text { Sustainability (Switzerland) } \\
\text { Journal Of Cleaner Production }\end{array}$ & $\begin{array}{l}\text { Pfau et al., 2014; Bugge et al., } 2016 \\
\text { D'Amato et al., } 2017\end{array}$ \\
\hline Tourism & $\begin{array}{l}\text { Journal Of Cleaner Production } \\
\text { Journal of Enterprising Communities }\end{array}$ & $\begin{array}{l}\text { Balata and Tola } 2016 \\
\text { Turner et al., } 2012\end{array}$ \\
\hline
\end{tabular}


Table A3. Publications on the GE by categories.

\begin{tabular}{|c|c|c|}
\hline Categories & Journals & Authors/Year of Publication \\
\hline $\begin{array}{l}\text { Design } \\
\text { or policy } \\
\text { analysis }\end{array}$ & $\begin{array}{l}\text { Actual Problems of Economics } \\
\text { Applied Energy } \\
\text { Asian Social Science } \\
\text { Capital and Class } \\
\text { Cities } \\
\text { Comparative Economic Research } \\
\text { Economic Development Quarterly } \\
\text { Economy and Society } \\
\text { Economy of Regions } \\
\text { Energy Economics } \\
\text { Environmental and Resource Economics } \\
\text { Espacios } \\
\text { Futures } \\
\text { Globalizations } \\
\text { International Environmental Agreements: Politics, Law } \\
\text { and Economics } \\
\text { International Journal of Ecological Economics and Statistics } \\
\text { International Journal of Economics and Financial Issues } \\
\text { International Journal of Energy Economics and Policy } \\
\text { International Journal of Green Economics } \\
\text { International Journal of Technology and Globalisation } \\
\text { Journal Of Cleaner Production } \\
\text { Law and Development Review } \\
\text { Local Economy } \\
\text { Progress in Industrial Ecology } \\
\text { Quality-Access to Success } \\
\text { Resource and Energy Economics } \\
\text { Review of International Political Economy } \\
\text { Scandinavian Journal of Economics }\end{array}$ & $\begin{array}{l}\text { Nekos and Soloshych 2014; Dziura } 2016 \\
\text { Yushchenko and Patel } 2016 \\
\text { Bassi et al., } 2014 \\
\text { Holgersen and Warlenius } 2016 \\
\text { Ahmad et al., } 2013 \\
\text { Wysokińska } 2013 \\
\text { Harper-Anderson } 2012 \\
\text { Janković and Bowman } 2014 \\
\text { Bobylev et al., } 2015 \\
\text { Schmalensee } 2012 \\
\text { Gronwald et al., } 2017 \\
\text { Apsalyamova et al., } 2017 \\
\text { Dulal et al., 2015 } \\
\text { Goodman and Salleh 2013 } \\
\text { Bratman 2014; McAfee 2016; Pickering and Mitchell 2017 } \\
\text { Onyusheva et al., 2017; Patlasov and Zharov 2017 } \\
\text { Dovgot'Ko et al., 2016 } \\
\text { Abdullah et al., 2017; Bakar et al., 2017; Matraeva et al., 2017; Akinyemi et al., 2017 } \\
\text { Yang 2009; Newton 2011; Chichilnisky 2011; Islam et al., 2012; Saidmamatov et al., 2014; } \\
\text { Kerckhoven et al., 2015; Megwai et al., 2016 } \\
\text { Schmitz 2015 } \\
\text { Granek 2011; Puppim De Oliveira et al., 2013; Droste et al., 2016; Chen et al., 2017; } \\
\text { Guillen-Royo et al., 2017; Weber and Cabras 2018 } \\
\text { Tania 2013 } \\
\text { James and Cato 2014 } \\
\text { Zenchanka and Korshuk 2015; Folcut and Grigore 2016; Zaharia 2016 } \\
\text { Ciobanu and Velciu 2011; Ciobanu et al., 2014; Boboc et al., 2015 } \\
\text { Barbier 2016 } \\
\text { Brand and Wissen 2013 } \\
\text { Goeschl and Perino 2017 }\end{array}$ \\
\hline
\end{tabular}


Table A3. Cont.

\begin{tabular}{|c|c|c|}
\hline Categories & Journals & Authors/Year of Publication \\
\hline & $\begin{array}{l}\text { Simulation and Gaming } \\
\text { South African Journal of Economic and Management Sciences } \\
\text { Technological Forecasting and Social Change } \\
\text { Technology Analysis and Strategic Management } \\
\text { Transformations in Business and Economics } \\
\text { World Development }\end{array}$ & $\begin{array}{l}\text { Bassi et al., } 2015 \\
\text { Ettmayr and Lloyd } 2017 \\
\text { Musango et al., } 2014 \\
\text { Steward } 2012 \\
\text { Rakauskiene and Okuneviciute-Neverauskiene } 2015 \\
\text { Never and Betz } 2014\end{array}$ \\
\hline $\begin{array}{l}\text { Sectorial } \\
\text { application/ } \\
\text { clusters }\end{array}$ & $\begin{array}{l}\text { Applied Energy } \\
\text { Academy of Strategic Management Journal } \\
\text { Ecological Economics } \\
\text { Espacios } \\
\text { Forest Policy and Economics } \\
\text { Green Economic Structures in Modern Business and Society } \\
\text { Green in Software Engineering } \\
\text { International Business Management } \\
\text { International Journal of Economic Research } \\
\text { International Journal of Energy Economics and Policy } \\
\text { International Journal of Green Economics } \\
\text { International Journal of Technology and Globalisation } \\
\text { Journal of Environmental Economics and Management } \\
\text { Journal of Cleaner Production } \\
\text { Marine Policy } \\
\text { Review of International Political Economy } \\
\text { Sustainable Technologies, Policies, and Constraints in the } \\
\text { Green Economy } \\
\text { Technology Analysis and Strategic Management } \\
\text { Technological Forecasting and Social Change } \\
\text { World Development }\end{array}$ & $\begin{array}{l}\text { Li and Lin } 2017 \\
\text { Apsalyamova et al., } 2017 \\
\text { Caparrós et al., } 2017 \\
\text { Dudin et al., } 2017 \\
\text { Kalonga and Kulindwa 2017; Kröger 2017 } \\
\text { Guz and Ivolga 2015; Lescheva and Ivolga } 2015 \\
\text { Calero and Piattini } 2015 \\
\text { Kundius et al., } 2016 \\
\text { Dudin et al., 2016 } \\
\text { Dudin et al., 2017; Dudin et al., } 2017 \\
\text { Sultan 2013 } \\
\text { Kumar and Sinha } 2014 \\
\text { Walls et al., 2017 } \\
\text { Hurmekoski et al., } 2017 \\
\text { Christiansen 2017 } \\
\text { DiMuzio 2012 } \\
\text { Jean-Vasile 2013; Filipović et al., 2013; Jean-Vasile et al., } 2013 \\
\text { Kedron and Bagchi-Sen } 2017 \\
\text { Gouvea et al., 2013 } \\
\text { Montefrio and Dressle } 2016\end{array}$ \\
\hline Case study & $\begin{array}{l}\text { Ecological Economics } \\
\text { International Journal of Green Economics } \\
\text { Journal Of Cleaner Production } \\
\text { New Technology, Work and Employment } \\
\text { Quality-Access to Success } \\
\text { Resources Conservation And Recycling }\end{array}$ & $\begin{array}{l}\text { Watson et al., } 2016 \\
\text { Aryal et al., } 2015 \\
\text { Pitkänen et al., } 2016 \\
\text { Bozkurt and Stowell } 2016 \\
\text { Verde 2015; Selvaggi 2017; Ciobanu et al., } 2017 \\
\text { Ferrão et al., } 2014\end{array}$ \\
\hline
\end{tabular}


Table A3. Cont.

\begin{tabular}{|c|c|c|}
\hline Categories & Journals & Authors/Year of Publication \\
\hline \multirow{5}{*}{$\begin{array}{l}\text { Consumer } \\
\text { behaviour }\end{array}$} & Business Strategy and the Environment & Mustonen et al., 2016 and Hinnen et al., 2017 \\
\hline & Ecological Economics & Bauwens et al., 2017; Yadav and Pathak 2017 \\
\hline & International Journal of Green Economics & Widihasta 2013; Pratiwi 2013; Taufique et al., 2014 \\
\hline & Journal of Policy Modeling & Garces-Voisenat and Mukherjee 2016 \\
\hline & Journal of Promotion Management & Bresciani et al., 2016 \\
\hline \multirow{10}{*}{$\begin{array}{l}\text { Management } \\
\text { Styles }\end{array}$} & Actual Problems of Economics & Bryzhan 2016 \\
\hline & Business Strategy and the Environment & Perez-Valls et al., 2016 \\
\hline & Contributions to Economics & Melikhov et al., 2017 \\
\hline & Ecological Economics & Elliott and Lindley 2017 \\
\hline & Economic Modelling & Carfi and Schilirò 2012 \\
\hline & Journal Of Cleaner Production & Lorek and Spangenberg 2014; McCormick et al., 2016; Aiello et al., 2016 \\
\hline & Quality-Access to Success & Andreica et al., 2014 \\
\hline & Resources Conservation And Recycling & Carvalho et al., 2017; Shen et al., 2017 \\
\hline & Review of Radical Political Economics & Kenis and Lievens 2016 \\
\hline & Sustainability (Switzerland) & Zhang et al., 2016; Guo et al.,2017 \\
\hline \multirow{2}{*}{$\begin{array}{c}\text { SMEs/family } \\
\text { businesses }\end{array}$} & Resource and Energy Economics & Cecere and Mazzanti 2017 \\
\hline & Industry and Innovation & Muscio et al., 2017 \\
\hline \multirow{4}{*}{$\begin{array}{l}\text { Corporate Social } \\
\text { Responsibility }\end{array}$} & Ecological Economics & Maggioni and Santangelo 2017 \\
\hline & Progress in Industrial Ecology & Touny and Shusha 2015 \\
\hline & Quality-Access to Success & Viola et al., 2013; Bran et al., 2013 \\
\hline & Sustainability Accounting, Management and Policy Journal & Weber 2017 \\
\hline \multirow{4}{*}{ Education } & Journal Of Cleaner Production & Leire et al., 2016 \\
\hline & Problems and Perspectives in Management & Nhamo 2014; Ahmad et al., 2015 \\
\hline & Progress in Industrial Ecology & Anghelutǎ 2016 \\
\hline & Quality-Access to Success & Angheluţă 2016 \\
\hline \multirow{8}{*}{ Indicators } & Journal Of Cleaner Production & Houshyar et al., 2015 \\
\hline & Environmental Economics and Policy Studies & Endriana et al., 2015 \\
\hline & International Journal of Social Economics & Lane 2011 \\
\hline & Journal Of Applied Economic Sciences & Markina and Sharkova 2014 \\
\hline & Progress in Industrial Ecology & Aceleanu 2015 \\
\hline & Social and Economic Studies & Moore et al., 2015 \\
\hline & Sustainability (Switzerland) & $\mathrm{Li}$ and $\operatorname{Lin} 2016$ \\
\hline & Technological Forecasting and Social Change & Valle and Clímaco 2015 \\
\hline
\end{tabular}


Table A3. Cont.

\begin{tabular}{|c|c|c|}
\hline Categories & Journals & Authors/Year of Publication \\
\hline \multirow{6}{*}{ Innovation } & Ecological Economics & Antonioli and Mazzanti 2017 \\
\hline & Economics and Sociology & Urbaniec 2015 \\
\hline & Industry and Innovation & Faria and Andersen 2017 \\
\hline & Journal of Economic Geography & Davies and Mullin 2011 \\
\hline & Quality-Access to Success & Chapple et al., 2011 \\
\hline & Technological Forecasting and Social Change & Mazzanti and Rizzo 2017; Faria and Andersen 2017 \\
\hline \multirow{2}{*}{ Investment } & Journal of Economic Issues & Warnecke 2015 \\
\hline & Quality-Access to Success & Dobre and Boboc 2013 \\
\hline \multirow{4}{*}{$\begin{array}{l}\text { Theoretical/ } \\
\text { conceptual } \\
\text { framework }\end{array}$} & Futures & Vazquez-Brust et al., 2014 \\
\hline & Prague Economic Papers & Kasztelan 2017 \\
\hline & Quality-Access to Success & Bran 2011 y 2013; Curea 2011; Bran 2013; Ciobotaru and Anghelută 2014 \\
\hline & Small Business Economics & Demirel et al., 2017 \\
\hline \multirow{4}{*}{ Others } & Quality-Access to Success & Antonescu 2014 \\
\hline & GAIA & Wäger 2011 \\
\hline & International Journal of Green Economics & Kennet 2009; Bruyeré and Filiberto 2013 \\
\hline & Transitions to Sustainability & Lopes 2015 \\
\hline \multirow{3}{*}{$\begin{array}{c}\text { Literature } \\
\text { review }\end{array}$} & International Environmental Agreements: Politics, Law and & Ehresman and Okereke 2014 \\
\hline & Journal Of Cleaner Production & Loiseau et al., 2016 \\
\hline & Technology in Society & Tariq et al., 2017 \\
\hline \multirow{6}{*}{ Tourism } & Bridging Tourism Theory and Practice & DeLacy and Lipman 2010 \\
\hline & Journal Of Cleaner Production & Law et al., 2013 \\
\hline & Journal of Internet Banking and Commerce & Dzhusibalieva et al., 2016 \\
\hline & Journal of Sustainable Tourism & Law et al., 2012 y 2017 \\
\hline & Tourism Geographies & Duffy 2015 \\
\hline & Tourism Recreation Research & Holden 2013 y 2015 \\
\hline
\end{tabular}




\section{References}

1. Ramcilovic-Suominen, S.; Pülzl, H. Sustainable development-A 'selling point' of the emerging EU bioeconomy policy framework? J. Clean. Prod. 2016, 172, 4170-4180. [CrossRef]

2. Costanza, R.; Daly, H.E.; Biology, C. Natural Capital and Sustainable Development. Conserv. Biol. 1992, 6, 37-46. [CrossRef]

3. Wackernagel, M.; Onisto, L.; Bello, P.; Linares, A.C.; Falfan, I.S.L.; Garcia, J.M.; Guerrero, A.I.S.; Guerrero, M.G.S. National natural capital accounting with the ecological footrpint concept. Ecol. Econ. 1999, 29, 375-390. [CrossRef]

4. United Nations. The 2030 Agenda for Sustainble Development. New York. Available online: http:/ / www. un.org/ga/search/view_doc.asp?symbol=A/RES/70/1\&Lang=E (accessed on 19 May 2015).

5. European Commission. European Bioeconomy Stakeholders Manifesto; Brussels. Available online: https: / / ec.europa.eu/research/bioeconomy/pdf/european_bioeconomy_stakeholders_manifesto.pdf (accessed on 29 April 2017).

6. Staffas, L.; Gustavsson, M.; McCormick, K. Strategies and policies for the bioeconomy and bio-based economy: An analysis of official national approaches. Sustainability 2013, 5, 2751-2769. [CrossRef]

7. European Commission. A Resource-Efficient Europe-Flagship Initiative under the Europe 2020 Strategy; European Commission: Brussels, Belgium, 2011.

8. Meyer, R. Bioeconomy strategies: Contexts, visions, guiding implementation principles and resulting debates. Sustainability 2017, 9, 1031. [CrossRef]

9. De Besi, M.; McCormick, K. Towards a bioeconomy in Europe: National, regional and industrial strategies. Sustainability 2015, 7, 10461-10478. [CrossRef]

10. D'Amato, D.; Droste, N.; Allen, B.; Kettunen, M.; Lähtinen, K.; Korhonen, J.; Leskinen, P.; Matthies, B.D.; Toppinen, A. Green, circular, bio economy: A comparative analysis of sustainability avenues. J. Clean. Prod. 2017, 168, 716-734. [CrossRef]

11. Le Blanc, D. Special issue on green economy and sustainable development. Nat. Resour. Forum 2011, 35, 151-154. [CrossRef]

12. UNEP. Towards a Green Economy: Pathways to Sustainable Development and Poverty Eradication.Nairobi. Available online: https:/ / sustainabledevelopment.un.org/content/documents/126GER_synthesis_en.pdf (accessed on 19 March 2011).

13. Su, B.; Heshmati, A.; Geng, Y.; Yu, X. A review of the circular economy in China: Moving from rhetoric to implementation. J. Clean. Prod. 2013, 42, 215-227. [CrossRef]

14. Ghisellini, P.; Cialani, C.; Ulgiati, S. A review on circular economy: The expected transition to a balanced interplay of environmental and economic systems. J. Clean. Prod. 2016, 114, 11-32. [CrossRef]

15. Geissdoerfer, M.; Savaget, P.; Bocken, N.M.P.; Hultink, E.J. The Circular Economy-A new sustainability paradigm? J. Clean. Prod. 2017, 143, 757-768. [CrossRef]

16. Urbinati, A.; Chiaroni, D.; Chiesa, V. Towards a new taxonomy of circular economy business models. J. Clean. Prod. 2017, 168, 487-498. [CrossRef]

17. Kirchherr, J.; Reike, D.; Hekkert, M. Conceptualizing the circular economy: An analysis of 114 definitions. Resour. Conserv. Recycl. 2017, 127, 221-232. [CrossRef]

18. Ellen Macarthur Foundation. Towards the Circular Economy. Available online: http:// circularfoundation. org/sites/default/files/tce_report1_2012.pdf (accessed on 7 April 2013).

19. Loiseau, E.; Saikku, L.; Antikainen, R.; Droste, N.; Hansjürgens, B.; Pitkänen, K.; Leskinen, P.; Kuikman, P.; Thomsen, M. Green economy and related concepts: An overview. J. Clean. Prod. 2016, 139, 361-371. [CrossRef]

20. European Commission. Innovating for Sustainable Growth: A Bioeconomy for Europe; European Commission: Brussels, Belgium, 2012.

21. Aguilar, A.; Wohlgemuth, R.; Twardowski, T. Perspectives on bioeconomy. New Biotechnol. 2018, 40, 181-184. [CrossRef] [PubMed]

22. Bugge, M.M.; Hansen, T.; Klitkou, A. What is the bioeconomy? A review of the literature. Sustainability 2016, 8, 691. [CrossRef]

23. Hausknost, D.; Schriefl, E.; Lauk, C.; Kalt, G. A transition to which bioeconomy? An exploration of diverging techno-political choices. Sustainability 2017, 9, 669. [CrossRef] 
24. Lahti, T.; Wincent, J.; Parida, V. A Definition and Theoretical Review of the Circular Economy, Value Creation, and Sustainable Business Models: Where Are We Now and Where Should Research Move in the Future? Sustainability 2018, 10, 2799. [CrossRef]

25. Merli, R.; Preziosi, M.; Acampora, A. How do scholars approach the circular economy? A systematic literature review. J. Clean. Prod. 2018, 178, 703-722. [CrossRef]

26. Tranfield, D.; Denyer, D.; Smart, P. Towards a Methodology for Developing Evidence-Informed Management Knowledge by Means of Systematic Review. Br. J. Manag. 2003, 14, 207-222. [CrossRef]

27. Falagas, M.E.; Pitsouni, E.I.; Malietzis, G.A.; Pappas, G. Comparison of PubMed, Scopus, Web of Science, and Google Scholar: Strengths and weaknesses. FASEB J. 2007, 22, 338-342. [CrossRef] [PubMed]

28. Prieto-Sandoval, V.; Jaca, C.; Ormazabal, M. Towards a consensus on the circular economy. J. Clean. Prod. 2018, 179, 605-615. [CrossRef]

29. Silverman, M.; Ricci, E.M.; Gunter, M.J. Strategies for Increasing the Rigor of Qualitative Methods in Evaluation of Health Care Programs. Eval. Rev. 1990, 14, 57-74. [CrossRef]

30. Jurgilevich, A.; Birge, T.; Kentala-Lehtonen, J.; Korhonen-Kurki, K.; Pietikäinen, J.; Saikku, L.; Schösler, H. Transition towards circular economy in the food system. Sustainability 2016, 8, 69. [CrossRef]

31. Kuisma, M.; Kahiluoto, H. Biotic resource loss beyond food waste: Agriculture leaks worst. Resour. Conserv. Recycl. 2017, 124, 129-140. [CrossRef]

32. Abu-Ghunmi, D.; Abu-Ghunmi, L.; Kayal, B.; Bino, A. Circular economy and the opportunity cost of not "closing the loop" of water industry: The case of Jordan. J. Clean. Prod. 2016, 131, 228-236. [CrossRef]

33. Maaß, O.; Grundmann, P. Added-value from linking the value chains of wastewater treatment, crop production and bioenergy production: A case study on reusing wastewater and sludge in crop production in Braunschweig (Germany). Resour. Conserv. Recycl. 2016, 107, 195-211. [CrossRef]

34. Whalen, K.A.; Milios, L.; Nussholz, J. Bridging the gap: Barriers and potential for scaling reuse practices in the Swedish ICT sector. Resour. Conserv. Recycl. 2017, 1-9. [CrossRef]

35. Park, J.; Sarkis, J.; Wu, Z. Creating integrated business and environmental value within the context of China's circular economy and ecological modernization. J. Clean. Prod. 2010, 18, 1492-1499. [CrossRef]

36. Gnoni, M.G.; Mossa, G.; Mummolo, G.; Tornese, F.; Verriello, R. Circular Economy Strategies for Electric and Electronic Equipment: A Fuzzy Cognitive Map. Environ. Eng. Manag. J. 2017, 16, 1807-1817.

37. Wieser, H. Beyond Planned Obsolescence. Gaia 2016, 156-160. [CrossRef]

38. Parajuly, K.; Wenzel, H. Potential for circular economy in household WEEE management. J. Clean. Prod. 2017, 151, 272-285. [CrossRef]

39. Tecchio, P.; McAlister, C.; Mathieux, F.; Ardente, F. In search of standards to support circularity in product policies: A systematic approach. J. Clean. Prod. 2017, 168, 1533-1546. [CrossRef] [PubMed]

40. Huang, B.; Wang, X.; Kua, H.; Geng, Y.; Bleischwitz, R.; Ren, J. Construction and demolition waste management in China through the 3R principle. Resour. Conserv. Recycl. 2018, 129, 36-44. [CrossRef]

41. Jiménez-Rivero, A.; García-Navarro, J. Best practices for the management of end-of-life gypsum in a circular economy. J. Clean. Prod. 2018, 167, 1335-1344. [CrossRef]

42. Strebel, H.; Posch, A. Interorganisational cooperation for sustainable management in industry: On industrial recycling networks and sustainability networks. Prog. Ind. Ecol. Int. J. 2004, 1, 348-362. [CrossRef]

43. Martín Gómez, A.M.; Aguayo González, F.; Marcos Bárcena, M. Smart eco-industrial parks: A circular economy implementation based on industrial metabolism. Resour. Conserv. Recycl. 2018, 135, 58-69. [CrossRef]

44. Albino, V.; Fraccascia, L. The industrial symbiosis approach: A classification of business models. Procedia Environ. Sci. Eng. Manag. 2015, 2, 217-223.

45. Fraccascia, L.; Magno, M.; Albino, V. Business models for industrial symbiosis: A guide for firms. Procedia Environ. Sci. Eng. Manag. 2016, 3, 83-93.

46. Zhao, H.; Guo, S.; Zhao, H. Comprehensive benefit evaluation of eco-industrial parks by employing the best-worst method based on circular economy and sustainability. Environ. Dev. Sustain. 2018, 20, 1229-1253. [CrossRef]

47. Guo, B.; Geng, Y.; Sterr, T.; Dong, L.; Liu, Y. Evaluation of promoting industrial symbiosis in a chemical industrial park: A case of Midong. J. Clean. Prod. 2016, 135, 995-1008. [CrossRef]

48. Zhao, H.; Zhao, H.; Guo, S. Evaluating the comprehensive benefit of eco-industrial parks by employing multi-criteria decision making approach for circular economy. J. Clean. Prod. 2017, 142, 2262-2276. [CrossRef] 
49. Yu, C.; De Jong, M.; Dijkema, G.P.J. Process analysis of eco-industrial park development-The case of Tianjin, China. J. Clean. Prod. 2014, 64, 464-477. [CrossRef]

50. Wang, Q.; Deutz, P.; Chen, Y. Building institutional capacity for industrial symbiosis development: A case study of an industrial symbiosis coordination network in China. J. Clean. Prod. 2017, 142, 1571-1582. [CrossRef]

51. Shi, H.; Chertow, M.; Song, Y. Developing country experience with eco-industrial parks: A case study of the Tianjin Economic-Technological Development Area in China. J. Clean. Prod. 2010, 18, 191-199. [CrossRef]

52. Dong, L.; Zhang, H.; Fujita, T.; Ohnishi, S.; Li, H.; Fujii, M.; Dong, H. Environmental and economic gains of industrial symbiosis for Chinese iron/steel industry: Kawasaki's experience and practice in Liuzhou and Jinan. J. Clean. Prod. 2013, 59, 226-238. [CrossRef]

53. Hu, Y.; Wen, Z.; Lee, J.C.K.; Luo, E. Assessing resource productivity for industrial parks using adjusted raw material consumption (ARMC). Resour. Conserv. Recycl. 2017, 124, 42-49. [CrossRef]

54. Aid, G.; Eklund, M.; Anderberg, S.; Baas, L. Expanding roles for the Swedish waste management sector in inter-organizational resource management. Resour. Conserv. Recycl. 2017, 124, 85-97. [CrossRef]

55. Noya, I.; Aldea, X.; González-García, S.; Gasol, C.M.; Moreira, M.T.; Amores, M.J.; Marín, D.; Boschmonart-Rives, J. Environmental assessment of the entire pork value chain in Catalonia-A strategy to work towards Circular Economy. Sci. Total Environ. 2017, 589, 122-129. [CrossRef] [PubMed]

56. Bartolacci, F.; Del Gobbo, R.; Paolini, A.; Soverchia, M. Waste management companies towards circular economy: What impacts on production costs? Environ. Eng. Manag. J. 2017, 16, 1789-1796.

57. Beccarello, M.; Di Foggia, G. Economic analysis of EU strengthened packaging waste recycling targets. J. Adv. Res. Law Econ. 2016, 7, 1930-1941. [CrossRef]

58. Salemdeeb, R.; Al-Tabbaa, A.; Reynolds, C. The UK waste input-output table: Linking waste generation to the UK economy. Waste Manag. Res. 2016, 34, 1089-1094. [CrossRef] [PubMed]

59. Supino, S.; Malandrino, O.; Testa, M.; Sica, D. Sustainability in the EU cement industry: The Italian and German experiences. J. Clean. Prod. 2016, 112, 430-442. [CrossRef]

60. Nasir, M.H.A.; Genovese, A.; Acquaye, A.A.; Koh, S.C.L.; Yamoah, F. Comparing linear and circular supply chains: A case study from the construction industry. Int. J. Prod. Econ. 2017, 183, 443-457. [CrossRef]

61. Han, F.; Liu, Y.; Liu, W.; Cui, Z. Circular economy measures that boost the upgrade of an aluminum industrial park. J. Clean. Prod. 2017, 168, 1289-1296. [CrossRef]

62. Zink, T.; Geyer, R.; Startz, R. Toward Estimating Displaced Primary Production from Recycling: A Case Study of U.S. Aluminum. J. Ind. Ecol. 2018, 22, 314-326. [CrossRef]

63. Ma, S.H.; Wen, Z.G.; Chen, J.N.; Wen, Z.C. Mode of circular economy in China's iron and steel industry: A case study in Wu'an city. J. Clean. Prod. 2014, 64, 505-512. [CrossRef]

64. Winning, M.; Calzadilla, A.; Bleischwitz, R.; Nechifor, V. Towards a circular economy: Insights based on the development of the global ENGAGE-materials model and evidence for the iron and steel industry. Int. Econ. Econ. Policy 2017, 14, 383-407. [CrossRef]

65. Sun, A. The establishment of the green tax policy in China-To accelerate the construction of circular economy experimental zone in Qaidam basin of Qinghai province as an example. Asian Soc. Sci. 2013, 9, 148-153. [CrossRef]

66. Liu, D.; Li, H.; Wang, W.; Dong, Y. Constructivism scenario evolutionary analysis of zero emission regional planning: A case of Qaidam Circular Economy Pilot Area in China. Int. J. Prod. Econ. 2012, 140, 341-356. [CrossRef]

67. Young, R. The Circular Economy in China. J. Mater. Cycles Waste Manag. 2007, 121-129. [CrossRef]

68. Mathews, J.A.; Tang, Y.; Tan, H. China's move to a Circular Economy as a development strategy. Asian Bus. Manag. 2011, 10, 463-484. [CrossRef]

69. Mo, H.; Wen, Z.; Chen, J. China's recyclable resources recycling system and policy: A case study in Suzhou. Resour. Conserv. Recycl. 2009, 53, 409-419. [CrossRef]

70. Wübbeke, J.; Heroth, T. Challenges and political solutions for steel recycling in China. Resour. Conserv. Recycl. 2014, 87, 1-7. [CrossRef]

71. Geng, Y.; Zhu, Q.; Doberstein, B.; Fujita, T. Implementing China's circular economy concept at the regional level: A review of progress in Dalian, China. Waste Manag. 2009, 29, 996-1002. [CrossRef] [PubMed] 
72. Guo, B.; Geng, Y.; Ren, J.; Zhu, L.; Liu, Y.; Sterr, T. Comparative assessment of circular economy development in China's four megacities: The case of Beijing, Chongqing, Shanghai and Urumqi. J. Clean. Prod. 2017, 162, 234-246. [CrossRef]

73. McDowall, W.; Geng, Y.; Huang, B.; Barteková, E.; Bleischwitz, R.; Türkeli, S.; Kemp, R.; Doménech, T. Circular Economy Policies in China and Europe. J. Ind. Ecol. 2017, 21, 651-661. [CrossRef]

74. Wysokińska, Z. The "New" environmental policy of the European Union: A path to development of a circular economy and mitigation of the negative effects of climate change. Comp. Econ. Res. 2016, 19, 57-73. [CrossRef]

75. Dalhammar, C. Industry attitudes towards ecodesign standards for improved resource efficiency. J. Clean. Prod. 2016, 123, 155-166. [CrossRef]

76. Bundgaard, A.M.; Mosgaard, M.A.; Remmen, A. From energy efficiency towards resource efficiency within the Ecodesign Directive. J. Clean. Prod. 2017, 144, 358-374. [CrossRef]

77. Golev, A.; Corder, G. Modelling metal flows in the Australian economy. J. Clean. Prod. 2016, 112, $4296-4303$. [CrossRef]

78. Raubenheimer, K.; McIlgorm, A. Is the Montreal Protocol a model that can help solve the global marine plastic debris problem? Mar. Policy 2017, 81, 322-329. [CrossRef]

79. Manomaivibool, P.; Hong, J.H. Two decades, three WEEE systems: How far did EPR evolve in Korea's resource circulation policy? Resour. Conserv. Recycl. 2014, 83, 202-212. [CrossRef]

80. Aguiñaga, E.; Henriques, I.; Scheel, C.; Scheel, A. Building resilience: A self-sustainable community approach to the triple bottom line. J. Clean. Prod. 2016, 173, 186-196. [CrossRef]

81. Ma, S.; Hu, S.; Chen, D.; Zhu, B. A case study of a phosphorus chemical firm's application of resource efficiency and eco-efficiency in industrial metabolism under circular economy. J. Clean. Prod. 2015, 87, 839-849. [CrossRef]

82. Li, Y.; Ma, C. Circular economy of a papermaking park in China: A case study. J. Clean. Prod. 2015, 92, 65-74. [CrossRef]

83. Liu, H.; Ou, X.; Yuan, J.; Yan, X. Experience of producing natural gas from corn straw in China. Resour. Conserv. Recycl. 2017, 135, 216-224. [CrossRef]

84. Deviatkin, I.; Havukainen, J.; Horttanainen, M. Comparative life cycle assessment of thermal residue recycling on a regional scale: A case study of South-East Finland. J. Clean. Prod. 2017, 149, 275-289. [CrossRef]

85. Richter, J.L.; Koppejan, R. Extended producer responsibility for lamps in Nordic countries: Best practices and challenges in closing material loops. J. Clean. Prod. 2016, 123, 167-179. [CrossRef]

86. Geng, Y.; Fu, J.; Sarkis, J.; Xue, B. Towards a national circular economy indicator system in China: An evaluation and critical analysis. J. Clean. Prod. 2012, 23, 216-224. [CrossRef]

87. Veleva, V.; Bodkin, G.; Todorova, S. The need for better measurement and employee engagement to advance a circular economy: Lessons from Biogen's “zero waste” journey. J. Clean. Prod. 2017, 154, 517-529. [CrossRef]

88. Franklin-Johnson, E.; Figge, F.; Canning, L. Resource duration as a managerial indicator for Circular Economy performance. J. Clean. Prod. 2016, 133, 589-598. [CrossRef]

89. Huysman, S.; De Schaepmeester, J.; Ragaert, K.; Dewulf, J.; De Meester, S. Performance indicators for a circular economy: A case study on post-industrial plastic waste. Resour. Conserv. Recycl. 2017, 120, 46-54. [CrossRef]

90. Linder, M.; Sarasini, S.; van Loon, P. A Metric for Quantifying Product-Level Circularity. J. Ind. Ecol. 2017, 21, 545-558. [CrossRef]

91. Molina-Moreno, V.; Leyva-Díaz, J.C.; Llorens-Montes, F.J.; Cortés-García, F.J. Design of indicators of circular economy as instruments for the evaluation of sustainability and efficiency in wastewater from pig farming industry. Water 2017, 9, 653. [CrossRef]

92. McCormick, K.; Kautto, N. The Bioeconomy in Europe: An Overview. Sustainability 2013, 5, $2589-2608$. [CrossRef]

93. Bell, J.; Paula, L.; Dodd, T.; Németh, S.; Nanou, C.; Mega, V.; Campos, P. EU ambition to build the world's leading bioeconomy-Uncertain times demand innovative and sustainable solutions. New Biotechnol. 2017, 40, 25-30. [CrossRef] [PubMed]

94. Wield, D. Bioeconomy and the global economy: Industrial policies and bio-innovation. Technol. Anal. Strateg. Manag. 2013, 25, 1209-1221. [CrossRef] 
95. Koukios, E.; Monteleone, M.; Texeira Carrondo, M.J.; Charalambous, A.; Girio, F.; Hernández, E.L.; Mannelli, S.; Parajó, J.C.; Polycarpou, P.; Zabaniotou, A. Targeting sustainable bioeconomy: A new development strategy for Southern European countries. The Manifesto of the European Mezzogiorno. J. Clean. Prod. 2018, 172, 3931-3941. [CrossRef]

96. Pannicke, N.; Gawel, E.; Hagemann, N.; Purkus, A.; Strunz, S. The political economy of fostering a wood-based bioeconomy in Germany. Ger. J. Agric. Econ. 2015, 64, 224-243.

97. Puttkammer, J.; Grethe, H. The Public Debate on Biofuels in Germany: Who Drives the Discourse? Ger. J. Agric. Econ. 2015, 64, 263-273.

98. Kröger, M.; Raitio, K. Finnish forest policy in the era of bioeconomy: A pathway to sustainability? For. Policy Econ. 2017, 77, 6-15. [CrossRef]

99. Lainez, M.; González, J.M.; Aguilar, A.; Vela, C. Spanish strategy on bioeconomy: Towards a knowledge based sustainable innovation. New Biotechnol. 2018, 40, 87-95. [CrossRef] [PubMed]

100. Kamal, N.; Dir, Z.C. Accelerating the Growth of Bioeconomy in Malaysia. J. Commer. Biotechnol. 2015, 21, 43-56. [CrossRef]

101. Sasson, A.; Malpica, C. Bioeconomy in Latin America. New Biotechnol. 2018, 40, 40-45. [CrossRef] [PubMed]

102. Arancibia, F. Challenging the bioeconomy: The dynamics of collective action in Argentina. Technol. Soc. 2013, 35, 79-92. [CrossRef]

103. Toppinen, A.; Pätäri, S.; Tuppura, A.; Jantunen, A. The European pulp and paper industry in transition to a bio-economy: A Delphi study. Futures 2017, 88, 1-14. [CrossRef]

104. Jenkins, T. Toward a biobased economy: Examples from the UK. Biofuels Bioprod. Biorefining 2008, 2, $133-143$. [CrossRef]

105. Van Meijl, H.; Tsiropoulos, I.; Bartelings, H.; Hoefnagels, R.; Smeets, E.; Tabeau, A.; Faaij, A. On the macro-economic impact of bioenergy and biochemicals-Introducing advanced bioeconomy sectors into an economic modelling framework with a case study for the Netherlands. Biomass Bioenergy 2018, 108, 381-397. [CrossRef]

106. Giurca, A.; Späth, P. A forest-based bioeconomy for Germany? Strengths, weaknesses and policy options for lignocellulosic biorefineries. J. Clean. Prod. 2017, 153, 51-62. [CrossRef]

107. Johansson, J. Participation and deliberation in Swedish forest governance: The process of initiating a National Forest Program. For. Policy Econ. 2016, 70, 137-146. [CrossRef]

108. Hagman, L.; Blumenthal, A.; Eklund, M.; Svensson, N. The role of biogas solutions in sustainable biorefineries. J. Clean. Prod. 2018, 172, 3982-3989. [CrossRef]

109. Ravera, F.; Scheidel, A.; Dell'Angelo, J.; Gamboa, G.; Serrano, T.; Mingorría, S.; Cabello, V.; Arizpe, N.; Ariza, P. Pathways of rural change: An integrated assessment of metabolic patterns in emerging ruralities. Environ. Dev. Sustain. 2014, 16, 811-820. [CrossRef]

110. Golembiewski, B.; Sick, N.; Bröring, S. Patterns of Convergence Within the Emerging Bioeconomy-The Case of the Agricultural and Energy Sector. Int. J. Innov. Technol. Manag. 2015, 12, 1550012. [CrossRef]

111. Lehtonen, O.; Okkonen, L. Regional socio-economic impacts of decentralised bioeconomy: A case of Suutela wooden village, Finland. Environ. Dev. Sustain. 2013, 15, 245-256. [CrossRef]

112. Heinonen, T.; Pukkala, T.; Mehtätalo, L.; Asikainen, A.; Kangas, J.; Peltola, H. Scenario analyses for the effects of harvesting intensity on development of forest resources, timber supply, carbon balance and biodiversity of Finnish forestry. For. Policy Econ. 2017, 80, 80-98. [CrossRef]

113. Pergola, M.; Piccolo, A.; Palese, A.M.; Ingrao, C.; Di Meo, V.; Celano, G. A combined assessment of the energy, economic and environmental issues associated with on-farm manure composting processes: Two case studies in South of Italy. J. Clean. Prod. 2018, 172, 3969-3981. [CrossRef]

114. Mustalahti, I. The responsive bioeconomy: The need for inclusion of citizens and environmental capability in the forest based bioeconomy. J. Clean. Prod. 2018, 172, 3781-3790. [CrossRef]

115. Scheiterle, L.; Ulmer, A.; Birner, R.; Pyka, A. From commodity-based value chains to biomass-based value webs: The case of sugarcane in Brazil's bioeconomy. J. Clean. Prod. 2018, 172, 3851-3863. [CrossRef]

116. Wesseler, J.; von Braun, J. Measuring the Bioeconomy: Economics and Policies. Annu. Rev. Resour. Econ. 2017, 9, 275-298. [CrossRef]

117. Ronzon, T.; Piotrowski, S.; M'Barek, R.; Carus, M. A systematic approach to understanding and quantifying the EU's bioeconomy. Bio-Based Appl. Econ. 2017, 6, 1-17. [CrossRef] 
118. Fuentes-Saguar, P.D.; Mainar-Causapé, A.J.; Ferrari, E. The role of bioeconomy sectors and natural resources in EU economies: A social accounting matrix-based analysis approach. Sustainability 2017, 9, 2383. [CrossRef]

119. Dulal, H.B.; Dulal, R.; Yadav, P.K. Delivering green economy in Asia: The role of fiscal instruments. Futures 2015, 73, 61-77. [CrossRef]

120. Dziura, B. Green economy and blue economy as alternative economic models in China (PRC). Actual Probl. Econ. 2016, 186, 215-221.

121. Chen, W.; Chen, J.; Xu, D.; Liu, J.; Niu, N.; Chen, W.; Chen, J. Assessment of the practices and contributions of China's green industry to the socio-economic development. J. Clean. Prod. 2017, 153, 648-656. [CrossRef]

122. Yang, P. Public finance and environment: Correlations of selected taxes with pollution and $\mathrm{CO}_{2}$ emissions in China between 1999 and 2006. Int. J. Green Econ. 2009, 3, 48. [CrossRef]

123. Islam, R.; Siwar, C.; Ludin, N.A.; Chowdhury, M.S.; Ibrahim, Y. Green economy: Assessing the greenness of the Malaysian economy. Int. J. Green Econ. 2012, 6, 226. [CrossRef]

124. Bakar, N.A.; Abdullah, H.; Ibrahim, F.W.; Jali, M.R.M. Green economy: Evaluation of Malaysian company environmental sustainability. Int. J. Energy Econ. Policy 2017, 7, 139-143.

125. Abdullah, H.; Bakar, N.A.; Jali, M.R.M.; Ibrahim, F.W. The current state of Malaysia's journey towards a green economy: The perceptions of the companies on environmental efficiency and sustainability. Int. J. Energy Econ. Policy 2017, 7, 253-258.

126. Droste, N.; Hansjürgens, B.; Kuikman, P.; Otter, N.; Antikainen, R.; Leskinen, P.; Pitkänen, K.; Saikku, L.; Loiseau, E.; Thomsen, M. Steering innovations towards a green economy: Understanding government intervention. J. Clean. Prod. 2016, 135, 426-434. [CrossRef]

127. Wysokińska, Z. Transition To A Green Economy In The Context Of Selected European And Global Requirements For Sustainable Development. Comp. Econ. Res. 2013, 16, 203-226. [CrossRef]

128. Guillen-Royo, M.; Guardiola, J.; Garcia-Quero, F. Sustainable development in times of economic crisis: A needs-based illustration from Granada (Spain). J. Clean. Prod. 2017, 150, 267-276. [CrossRef]

129. Folcut, O.; Grigore, N.R. EU's sustainable growth strategy: Some implications on Romanian labour market. Prog. Ind. Ecol. Int. J. 2016, 10, 79-89. [CrossRef]

130. Rakauskiene, O.G.; Okuneviciute-Neverauskiene, L. Strategic guidelines of increasing employment and reducing unemployment in the context of EU (Lithuanian case). Transform. Bus. Econ. 2015, 14, $224-253$.

131. Bobylev, S.N.; Kudryavtseva, O.V.; Yakovleva, Y.Y. Regional priorities of green economy 1. Экономика Региона 2015, 2, 148-160. [CrossRef]

132. Yushchenko, A.; Patel, M.K. Contributing to a green energy economy? A macroeconomic analysis of an energy efficiency program operated by a Swiss utility. Appl. Energy 2016, 179, 1304-1320. [CrossRef]

133. Kerckhoven, S.; Van Bécault, E.; Marx, A. Ecological tax reform initiatives in Africa. Int. J. Green Econ. 2015, 9, 58. [CrossRef]

134. Akinyemi, O.E.; Osabuohien, E.S.; Alege, P.O.; Ogundipe, A.A. Energy security, trade and transition to green economy in Africa. Int. J. Energy Econ. Policy 2017, 7, 1-17. [CrossRef]

135. Musango, J.K.; Brent, A.C.; Bassi, A.M. Modelling the transition towards a green economy in South Africa. Technol. Forecast. Soc. Chang. 2014, 87, 257-273. [CrossRef]

136. Granek, F. Business value of toxics reduction and pollution prevention planning. J. Clean. Prod. 2011, 19, 559-560. [CrossRef]

137. Bassi, A.M.; De Rego, F.; Harrisson, J.; Lombardi, N. WATERSTORY ILE: A Systemic Approach to Solve a Long-Lasting and Far-Reaching Problem. Simul. Gaming 2015, 46, 404-429. [CrossRef]

138. Pickering, J.; Mitchell, P. What drives national support for multilateral climate finance? International and domestic influences on Australia's shifting stance Acknowledgments. Int. Environ. Agreements Politics Law Econ. 2017, 17, 107-125. [CrossRef]

139. Tania, S.J. Is there a linkage between sustainable development and market access of LDCs? Law Dev. Rev. 2013, 6, 143-223. [CrossRef]

140. Barbier, E.B. Is green growth relevant for poor economies? Resour. Energy Econ. 2016, 45, 178-191. [CrossRef]

141. McAfee, K. Green economy and carbon markets for conservation and development: A critical view. Int. Environ. Agreements Politics Law Econ. 2016, 16, 333-353. [CrossRef]

142. Ciobanu, G.; Velciu, M. The objectives of Green economy building for the developing countries. Qual.-Access Success 2011, 12, 155-160. 
143. Sultan, R.M. A green industry for sustainable trade strategies: The case of the manufacturing sector in Mauritius. Int. J. Green Econ. 2013, 7, 162. [CrossRef]

144. Dudin, M.N.; Frolova, Y.Y.; Artemyeva, Y.A.; Bezbakh, V.V.; Shakirov, S.S. Business entities within the agro-industrial sector and present-day trends in "green" logistics in a climate of transformation of the world economy. Int. J. Econ. Res. 2016, 13, 2379-2390.

145. Kumar, N.V.; Sinha, N. Transition towards a green economy: Role of FDI. Int. J. Technol. Glob. 2014, 7, 288. [CrossRef]

146. Caparrós, A.; Oviedo, J.L.; Álvarez, A.; Campos, P. Simulated exchange values and ecosystem accounting: Theory and application to free access recreation. Ecol. Econ. 2017, 139, 140-149. [CrossRef]

147. Andreica, A.; Bălu, O.F.; Bălu, P.-E. Green Economy-From Theory To Practice. Qual.—Access Success 2014, 15, 523-530.

148. Bryzhan, I.A. Determining key industrial sectors for greening of Ukrainian Economy. Economía del medio ambientey protección ambiental 2016, 1, 173-181.

149. Guo, Z.; Liu, H.; Zhang, D.; Yang, J. Green Supplier Evaluation and Selection in Apparel Manufacturing Using a Fuzzy Multi-Criteria Decision-Making Approach. Sustainability 2017, 9, 650. [CrossRef]

150. Aiello, G.; Giovino, I.; Vallone, M.; Catania, P.; Argento, A. A decision support system based on multisensor data fusion for sustainable greenhouse management. J. Clean. Prod. 2016, 172, 4057-4065. [CrossRef]

151. Carvalho, H.; Govindan, K.; Azevedo, S.G.; Cruz-Machado, V. Modelling green and lean supply chains: An eco-efficiency perspective. Resour. Conserv. Recycl. 2017, 120, 75-87. [CrossRef]

152. Perez-Valls, M.; Cespedes-Lorente, J.; Moreno-Garcia, J. Green Practices and Organizational Design as Sources of Strategic Flexibility and Performance. Bus. Strateg. Environ. 2016, 25, 529-544. [CrossRef]

153. Bozkurt, Ö.; Stowell, A. Skills in the green economy: Recycling promises in the UK e-waste management sector. New Technol. Work Employ 2016, 31, 146-160. [CrossRef]

154. Ciobanu, G.; Balu, F.O.; Petrescu, I.E. Green work places and the necessity of measuring green economy. Qual.-Access Success 2017, 18, 226-230.

155. Ferrão, P.; Ribeiro, P.; Rodrigues, J.; Marques, A.; Preto, M.; Amaral, M.; Domingos, T.; Lopes, A.; Costa, E.I. Environmental, economic and social costs and benefits of a packaging waste management system: A Portuguese case study. Resour. Conserv. Recycl. 2014, 85, 67-78. [CrossRef]

156. Verde, C. Strategy and Green business model: The case of Carlsberg group. Qual.—Access Success 2015, 16, 75.

157. Pitkänen, K.; Antikainen, R.; Droste, N.; Loiseau, E.; Saikku, L.; Aissani, L.; Hansjürgens, B.; Kuikman, P.J.; Leskinen, P.; Thomsen, M. What can be learned from practical cases of green economy? -studies from five European countries. J. Clean. Prod. 2016, 139, 666-676. [CrossRef]

158. Aceleanu, M.I. Green jobs in a green economy: Support for a sustainable development. Prog. Ind. Ecol. An Int. J. 2015, 9, 341. [CrossRef]

159. Markina, I.; Sharkova, A. Assessment methodology for resource-efficient development of organizations in the context of the green economy. J. Appl. Econ. Sci. 2014, 9, 687-693.

160. Valle, R.; Clímaco, J. A new tool to facilitate quantitative assessment of green activities-A trial application for Rio de Janeiro. Technol. Forecast. Soc. Chang. 2015, 98, 336-344. [CrossRef]

161. Li, J.; Lin, B. Green economy performance and green productivity growth in China's cities: Measures and policy implication. Sustainability 2016, 8, 947. [CrossRef]

162. Houshyar, E.; Dalgaard, T.; Tarazkar, M.H.; Jørgensen, U. Energy input for tomato production what economy says, and what is good for the environment. J. Clean. Prod. 2015, 89, 99-109. [CrossRef]

163. European Commission. A Sustainable Bioeconomy for Europe: Strengthening the Connection between Economy, Society and the Environment; European Commission: Burssels, Belgium, 2018.

164. Junta de Andalucía. Estrategia Andaluza de Bioeconomía Circular. Available online: https: //www.juntadeandalucia.es/export/drupaljda/Estrategia_Andaluza_Bioeconomia_Circular_EABC_18. 09.2018.pdf (accessed on 8 October 2018).

165. Bioeconomy; Lewandowski, I. (Ed.) Springer International Publishing: Cham, Switzerland, 2018; ISBN 978-3-319-68151-1.

166. Ranta, V.; Aarikka-Stenroos, L.; Ritala, P.; Mäkinen, S.J. Exploring institutional drivers and barriers of the circular economy: A cross-regional comparison of China, the US, and Europe. Resour. Conserv. Recycl. 2017, 135, 70-82. [CrossRef] 
167. Jiao, W.; Boons, F. Policy durability of Circular Economy in China: A process analysis of policy translation. Resour. Conserv. Recycl. 2017, 117, 12-24. [CrossRef]

168. Patermann, C.; Aguilar, A. The origins of the bioeconomy in the European Union. New Biotechnol. 2018, 40, 20-24. [CrossRef] [PubMed]

169. Schmitz, H. How does China's rise affect the green transformation? Int. J. Technol. Glob. 2015, 8, 1. [CrossRef]

(c) (1) BY 